\title{
CONSTITUTION OF THE REPUBLIC OF SERBIA - SHORTER COMMENTARY ON ARTICLES (WHY IT MUST BE AMENDED?)
}

DOI: $10.47743 /$ rdc-2016-4-0004

Darian RAKITOVAN

PhD student, West University of Timișoara, Faculty of Law

\section{Abstract}

After the referendum, on the $8^{\text {th }}$ of November, 2006, the Assembly of the Republic of Serbia promulgated the currently valid Constitution of the Republic of Serbia.

However, from the moment of its adoption, this Constitution was subjected to a great deal of criticism. Even the manner of its adoption was disputed. Currently, there are numerous demands for its amendment. Political parties in Serbia also more or less agree that the current Constitution should be amended, especially in the light of European integrations. Most frequently heard objections are to the provisions regarding the too high number of deputies in the Parliament, the content of the preamble, provisions regarding judiciary, the matter of regionalization etc.

This paper reviews and provides a short commentary on certain provisions of the Constitution of the Republic of Serbia, which we deem necessary to be pointed out when debating this matter. Particular focus is placed on certain normative solutions which we believe are not adequately regulated, i.e. those provisions we believe should be altered in order to adapt this supreme legal act to the intentions of Serbia to become a full member of the European Union, and which are at the same time in the interest of the citizens of Serbia.

Keywords: the Constitution of the Republic of Serbia; commentary on articles; shortcomings; reasons to amend the Constitution; opinion of the Venice Commission

\section{Introduction}

Throughout its modern history, starting from the year 1835 until today, Serbia has had thirteen constitutions. Four of these constitutions were promulgated by Serbia as an independent country, while three were made when it was a vassal state under the Ottoman Empire, two in the time when it was part of the Kingdom of Serbs, Croats and 
Slovenes, and the Kingdom of Yugoslavia, and four as a member of the Federal People's Republic of Yugoslavia, later Socialist Federal Republic of Yugoslavia, and Federal Republic of Yugoslavia, and finally by State Union of Serbia and Montenegro.

After the collapse of SFRJ, the 1990's in Serbia, which were marked by wars and general social and political crisis, and later on by the creation of the Federal Republic of Yugoslavia and the downfall of the authoritarian regime of Slobodan Milošević in October of 2000, was a unique historical opportunity to end all ties with previous wrong politics by passing a new, modern and democratic constitution. However, even with the absolute majority in the Parliament held by new democratic parties, and the enormous support of the public and a real support of the international community, such an opportunity has unjustifiably been missed.

Only after six years, in 2006, a decision has been made to urgently and hurriedly promulgate a new Constitution ${ }^{1}$. Such a decision has been motivated by a referendum regarding the independence of Montenegro in May of 2006, and by intensified negotiations regarding the final status of Kosovo and Metohija. Then, Kosovo and Metohija was included in the new Constitution as a constituent part of the territory of Serbia, with the aim to defend this province as it was clear even then that soon Kosovo will declare its independence from Serbia. The official opinion of the political elite then in power, was that passing a new Constitution, the preamble of which would state that Kosovo is an integral part of the Republic of Serbia, will strengthen the struggle to keep Kosovo within Serbia's borders.

On the other hand, the initiated process of joining Serbia to the European Union imposed the need to coordinate the supreme legal act of the Republic of Serbia with European standards. In that sense, the constitutional text could no longer contain provisions regarding the existence of death penalty, and also, it was necessary to expand the scope of human, civil and minority rights, and to give more constitutional power to independent regulatory bodies, which were until then only defined by laws. For this reason, despite numerous objects of the Venice Commission of the European Council to the constitutional text and the manner in which the referendum was conducted, the European Union gave its support to amend the Constitution and call for a constitutional referendum in Serbia.

The very process of preparing and writing the text of the Constitution took place very quickly and was "shrouded in mystery". The teams of the president of the Republic Boris Tadić, the Prime Minister Vojislav Koštunica and the largest oppositional party Serbian Radical party of Vojislav Šešelj took part in the writing of the constitutional text. The group of party leaders and experts had determined after only two weeks of negotiations, that the proposed text was acceptable for all parliamentary political parties. It was a kind of compromise between various opinions regarding key matters related to state polity (the position of autonomous provinces, the procedure of

1 “Official Gazette of RS", no. 98/2006.

CONSTITUTIONAL LAW REVIEW 


\section{Constitution of the Republic of Serbia...}

amending the Constitution, the manner of electing national deputies, and state symbols). The general and expert public was insufficiently informed regarding the making of the text and had no opportunity to become familiar with draft versions of such text, nor to provide any opinion, objections or commentary. The representatives of national minorities have also been excluded from the process of writing the text of the Constitution. The demands of the head of the civil sector and the Autonomous Province of Vojvodina to postpone the promulgation of the text of the Constitution in order to organize public debate and get the opinion of the Assembly of Vojvodina about the submitted text, were not respected. The Proposed Constitution of the Republic of Serbia was given to the National Assembly to be adopted. The deputies of the National Assembly became familiar with the text of the Proposed Constitution only two hours before the voting. In a special sitting held on September $30^{\text {th }}$ in 2006, in the absence of any parliamentary debate and without any objections, the proposed text of the Constitution was adopted by acclamation. Out of 250 total national deputies, 242 voted for the proposed text of the Constitution.

In this manner, after very short negotiations between the major political leaders of governing parliamentary parties in Serbia, the proposed text of the Constitution of the Republic of Serbia was adopted.

The European Commission for Democracy through Law (Venice Commission) ${ }^{2}$, but also the expert public were of the opinion that the lack of public debate in the procedure of adopting the Constitution of Serbia brought into question its legitimacy.

This was followed by the confirmation of the Constitution in a referendum. Conducting the referendum was accompanied by a lack of transparency of the process and irregularities during the voting, as well as a strong pressure on the citizens by the media during the days of the voting. Significant financial means were invested in the campaign to conduct the referendum by the Government, in order to encourage the voter turnout in the referendum and promulgate the Constitution. The issue of the referendum was turned into a "patriotic" issue, and the purpose of the pre-referendum marketing campaign was to influence the "patriotic spirit" of the citizens, so that not voting or voting against the Proposed Constitution was condemned as an unpatriotic and undemocratic act.

The referendum was held on the $28^{\text {th }}$ and $29^{\text {th }}$ of October, which is a deviation from the regular electoral practice of one day voting. During the two days of the referendum, a media campaign was ongoing that pressured the citizens to vote for the referendum, which was justified by a consensus of the parliamentary parties regarding the exclusion of the rules of media silence before and during the voting. The two-day voting did not allow for the best control in all polling stations. Cases of multiple voting have been recorded, voting without necessary documents, and the fact that only in the last three

\footnotetext{
${ }^{2}$ European Commission for Democracy through Law (Venice Commission), Opinion on the Constitution of Serbia, no. 405/2006 from March $19^{\text {th }} 2007$.
}

CONSTITUTIONAL JURISDICTIONS 
hours of the voting on the second day of the referendum, the same number of voters voted as the previous day and a half (?!). Even though the preamble states that the province of Kosovo and Metohija is a part of Serbia, persons belonging to Albanian nationality in Kosovo did not have the right to vote in the referendum, considering that voter's register for the elections after the year 2000 was used where these voters were not registered. By a decision of the Republic electoral commission, the Albanians from Kosovo were granted the option of voting in the referendum only if they are entered into the voter's register.

Even with the numerous irregularities accompanying the voting, the new Constitution was upheld in the referendum. According to the final results of the Republic electoral commission, there was a $54.91 \%$ voter turnout, or 3.645 .517 voters, and 3.521 .724 voted for the new Constitution, i.e. $53.04 \%$ of the total number of citizens with the right to vote. Following this, the Constitution of the Republic of Serbia was promulgated in the National Assembly on the $8^{\text {th }}$ of November, 2006.

Unfortunately, the initial fears of the expert public and the civil sector that the expedited process of making and adopting the Constitution will reflect unfavorably on its content and quality came true. In time, it became increasingly clear that this Constitution contains a series of bad and insufficiently defined solutions, numerous unclear or contradictory phrasings and other shortcomings of technical and legal nature.

In its report made six months after adopting the Constitution, the Venice Commission stated that "in its background of a hasty adoption it is particularly surprising that the Constitution is extremely rigid and that large parts are very difficult to amend $(\ldots)^{3}$. There are certain provisions that are still below the level of European standards as well as others that are contradictory or unclear, obviously as a result of careless writing" ${ }^{4}$.

In order to provide a comprehensive discussion on the matter of the Constitution, and as to reach an integral and compact analysis of the highest legal act in the Republic of Serbia, certain provisions of the Constitution of the Republic of Serbia, which we believe are necessary to be pointed out when speaking of this matter, will be presented and shortly commented upon. Apart from this, special focus will be placed on certain normative solutions, which we believe are not adequately regulated, i.e. those provisions which we deem should be altered in order to adapt this highest legal act to the intentions of Serbia to become a fully legal member of the European union, and which are, at the same time, in the interest of the citizens of Serbia. We point out the fact that most of the objections regarding the text of the Constitution presented in the continuation of the text, in great measure correspond with the objections of the European Commission for Democracy through Law (Venice Commission), provided in the Opinion regarding the Constitution of Serbia from March of 2007.

\footnotetext{
${ }^{3}$ Venice Commission, Opinion on the Constitution of Serbia, no. 405/2006, para. 104.

${ }^{4}$ Venice Commission, Opinion on the Constitution of Serbia, no. 405/2006, para. 5.
}

\section{CONSTITUTIONAL LAW REVIEW}




\section{Constitution of the Republic of Serbia}

The Constitution of the Republic of Serbia consists of the preamble and 206 Articles grouped in ten sections, which are:

1. Constitution principles;

2. Human and minority rights and freedoms;

3. Economic system and public finances;

4. Competencies of the Republic of Serbia;

5. Organization of government;

6. The constitutional court;

7. Territorial organization;

8. Constitutionality and legality;

9. Amending the constitution, and;

10. Final provision.

\section{Preamble}

Considering the state tradition of the Serbian people and equality of all citizens and ethnic communities in Serbia, considering also that the Province of Kosovo and Metohija is an integral part of the territory of Serbia, that it has the status of a substantial autonomy within the sovereign state of Serbia and that from such status of the Province of Kosovo and Metohija follow constitutional obligations of all state bodies to uphold and protect the state interests of Serbia in Kosovo and Metohija in all internal and foreign political relations, the citizens of Serbia adopt the Constitution of the Republic of Serbia.

The Constitution of the Republic of Serbia is of the type that begins with a preamble.

Theoretically speaking, the preamble is a part of the Constitution preceding the normative section, with a clear separation, and it represents a ceremonious statement of the political-program kind.

The preamble of the Constitution of Serbia (as well as the normative section of it) does not explicitly state the legal nature of the preamble, nor its effect, therefore, the question whether the provisions contained in it are legally binding remains open.

However, by closely analyzing the text of the preamble that particularly emphasizes Kosovo and Metohija (it is mentioned three times), which it considers an integral part of the territory of Serbia and which has a substantial autonomy within the sovereign country of Serbia, it can be concluded that the preamble does not have a particular legal strength apart from being declarative, as it, in essence, does not reflect the realistic state of the matter. What is without a doubt, is the fact that such preamble text, 


\section{Darian RAKITOVAN}

regardless the fact that it does not have a considerable legal power, definitely hinders communication with the international community, and that at this time, it is a real obstacle for Serbia for its goal of reaching European integrations.

In the opinion of the Venice Commission, it was pointed out that the Constitution indicates that the matter of the substantial autonomy of Kosovo and Metohija was delegated to the legislator in every aspect, and that accordingly, substantial autonomy depends on the will of the National Assembly in every regard ${ }^{5}$. The possibility of limiting the autonomy of the Provinces was legally confirmed in almost every article of part VII of the Constitution, for example: "The substantial autonomy of the Autonomous province of Kosovo and Metohija shall be regulated by the special law which shall be adopted in accordance with the proceedings envisaged for amending the Constitution" (Article 182 para. 2); "Territory of autonomous provinces and the terms under which borders between autonomous provinces may be altered shall be regulated by the Law..." (Article 182 para. 4); "Autonomous provinces shall, in accordance with the Law, regulate the matters of provincial interest in the following fields..." (Article 183 para. 2); "Autonomous provinces shall see to exercising human and minority rights, in accordance with the Law" (Article 183 para. 3); "Autonomous provinces shall manage the provincial assets in the manner stipulated by the Law" (Article 183 para. 6); "Autonomous provinces shall, in accordance with the Constitution and the Law, have direct revenues..." (Article 183 para. 6); "An autonomous province shall have direct revenues for financing its competences. A kind and amount of direct revenues shall be stipulated by the Law. The Law shall specify the share of autonomous provinces in the part of revenue of the Republic of Serbia" (Article 184 para. 1-3) etc.

As a result, contrary what is "firmly and with determination" proclaimed in the Preamble, the Constitution itself does not guarantee substantial autonomy of Kosovo and Metohija, as it depends on the will of the legislative in all aspects.

On the other hand, AP Vojvodina is left out of the Preamble, as if it were not an integral part of the territory of Serbia. Furthermore, this raises the question why the expression substantial autonomy is only used for Kosovo and Metohija, while no such type of autonomy is used when speaking of Vojvodina.

\section{Section one - Constitution Principles}

The first part of the Constitution, titled "Constitution principles", consists of 17 articles that encompass the basic principles which the constitutional system of the Republic of Serbia rests on. Based on their content, these principles can be divided into three groups:

\footnotetext{
${ }^{5}$ Venice Commission, Opinion on the Constitution of Serbia, no. 405/2006, para. 13.
}

\section{CONSTITUTIONAL LAW REVIEW}




\section{Constitution of the Republic of Serbia...}

1) General principles (rule of law, division of power, sovereignty of citizens, political pluralism, secularity of the state, the right of the citizens to provincial autonomy and local self-government, and prohibition of the conflict of interests);

2) The principles related to human and minority rights (guaranteeing gender equality, protection of Serbs abroad, protection of national minorities, and basic guarantees for foreign nationals), and

3) Constitutional provisions related to formal symbols of the country (provisions regarding: the definition of the Republic, national symbols (coat of arms, anthem and flag), territory and borders, capital city, and international relations).

\section{Article 1. Republic of Serbia}

Republic of Serbia is a state of Serbian people and all citizens who live in it, based on the rule of law and social justice, principles of civil democracy, human and minority rights and freedoms, and commitment to European principles and values.

The Constitution begins with a provision defining Serbia and determining its character, by stating the basic principles that it rests on as a political community and a constitutional country.

However, the phrasing "Republic of Serbia is a state of Serbian people and all citizens who live in it..." indicates that ethnic rather than civic definition of the country prevailed in the Constitution, based on which Serbia is a country of primarily Serbs, and then of other nations. The fact that in the first article of the Constitution one ethnic community is distinguished gives the impression that the members of other ethnic communities are second class citizens. Even though in practice such formulation should be of no consequence, creating a difference between the citizens based on their national or ethnic origin, infringes upon the universal principle of the equality of nations and negatively influences the firmness of the democratic basis of the state. Such provision is a step back compared to the Constitution from 1990, where Serbia is defined as "the country of all citizens that live in it" ${ }^{\text {, }}$ and it was criticized also by the Commission against racism and intolerance?

\section{Article 2. Sovereignty holders}

Sovereignty is vested in citizens who exercise it through referendums, people's initiative and freely elected representatives.

No state body, political organization, group or individual may usurp the sovereignty from the citizens, nor establish government against freely expressed will of the citizens.

\footnotetext{
${ }^{6}$ Article 1 of the Constitution of Serbia from 1990 ("The Official Gazette of RS", no. 1/90).

${ }^{7}$ European Commission against racism and intolerance, Report on Serbia, Strasbourg, 2008, adopted on December 14, 2007, p. 9.
} 
Classifying the principle of national (civic) sovereignty into the basic principles of the Constitution is a good solution which unequivocally shows that this principle is considered one of the founding principles of the constitutional system.

Apart from the principled position that "sovereignty is vested in citizens", it more closely regulates the forms of practical realization of national sovereignty principle. The realization of national sovereignty is done: indirectly, using representatives directly elected through free, fair, democratic and direct lections; and b) indirectly - by referendum and national initiative.

In terms of referendum, the Constitution regulates:

- the issues decided by mandatory additional constitutional referendum (Article 203 para. 7 - The National Assembly shall be obliged to put forward the act on amending the Constitution in the republic referendum to have it endorsed, in cases when the amendment of the Constitution pertains to the preamble of the Constitution, principles of the Constitution, human and minority rights and freedoms, the system of authority, proclamation the state of war and emergency, derogation from human and minority rights in the state of emergency or war or the proceedings of amending the Constitution);

- the issues decided by a facultative constitutional referendum, the conditions for calling the referendum, calling the referendum, and all the subjects who demand the calling (Article 203 para. 6 - The National Assembly shall adopt an act on amending the Constitution by a two-third majority of the total number of deputies and may decide to have it endorsed in the republic referendum by the citizens);

- the issues mandatorily decided by the referendum (Article 182 para. 3 and $4-$ New autonomous provinces may be established, and already established ones may be revoked or merged following the proceedings envisaged for amending the Constitution. The proposal to establish new, or revoke or merge the existing autonomous provinces shall be established by citizens in a referendum, in accordance with the Law. Territory of autonomous provinces and the terms under which borders between autonomous provinces may be altered shall be regulated by the Law. Territory of autonomous provinces may not be altered without the consent of its citizens given in a referendum, in accordance with the Law);

- conditions under which facultative referendum is called for all other issues, and the subjects that can request the calling (Article 99 para. 1, p. 2 - National Assembly when deciding on changes concerning borders of the Republic of Serbia, and Art 108, para. 1 - Upon the request of the majority of all deputies or at least 100,000 voters, the National Assembly shall call the referendum on issues falling within its competence, in accordance with the Constitution and Law);

- the issues that cannot be the subject of a referendum (Article 108 para. 2 - The subject of the referendum may not include duties deriving from international contracts, laws pertaining to human and minority rights and freedoms, fiscal and other financial 


\section{Constitution of the Republic of Serbia...}

laws, the budget and financial statement, introduction of the state of emergency and amnesty, as well as issues pertaining to election competences of the National Assembly).

Civic initiative is a form of direct decision making of the citizens, by which the citizens initiate the decision-making or submit a formal proposal that initiates the proceedings regarding an issue.

The Constitution particularly regulates certain forms of civic initiative:

- legislative initiative - the right of the citizens to propose a law (Article 107 para. 1 A right to propose laws, other regulations and general acts shall belong to every deputy, the Government, assemblies of autonomous provinces or at least 30,000 voters);

- constitutional initiative - the right of the citizens to propose revision of the Constitution (Article 203 para. 1 - A proposal to amend the Constitution may be submitted by at least one third of the total number of deputies, the President of the Republic, the Government and at least 150,000 voters);

- request for calling a referendum - the right of the citizens to request a calling of republic referendum (Article 108 para. 1 - Upon the request of the majority of all deputies or at least 100,000 voters, the National Assembly shall call the referendum on issues falling within its competence, in accordance with the Constitution and Law).

\section{Article 3. Rule of Law}

Rule of law is a fundamental prerequisite for the Constitution which is based on inalienable human rights.

The rule of law shall be exercised through free and direct elections, constitutional guarantees of human and minority rights, separation of power, independent judiciary and observance of Constitution and Law by the authorities.

\section{Article 4. Division of power}

The legal system is unique.

Government system shall be based on the division of power into legislative, executive and judiciary.

Relation between three branches of power shall be based on balance and mutual control.

Judiciary power shall be independent.

The relationship between the three basic branches of the government - legislative, executive and judicial according to the Constitution rests on the division of power principle. Therefore, apart from all the other limitations stipulated by the Constitution and the laws, the government is also subject to limitations set in place by this principle, which does not allow for unification of various functions of government under one authority.

The executive authority consists of the Government and the President of the Republic. Judicial authority consists of the courts: courts of general jurisdiction - basic, 


\section{Darian RAKITOVAN}

higher, appellational and the Supreme Court of Cassation - as well as courts of specialized jurisdiction - the economic courts, contravention courts and the Administrative Court - and legislative - National Assembly. According to this article of the Constitution, the two principles that the relations between the authorities of these "three branches of government" are based on are: first, that there is a "balance and mutual control" (para. 2), and second that "the judicial power is independent" (para. 3).

It can be noticed that these two paragraphs are contradictory, as it is not possible for one of the authorities to be independent, specifically - the judiciary, if the relationship between all three authorities is based on mutual control. In parliamentary systems, mutual control and balance of power is typical for relations between the legislative and executive authority, as has been relatively satisfactorily done in the Constitution of Serbia, which can be concluded from the numerous instruments concerning the relations of the Government and the National Assembly, for example: interpellation (Article 129), vote on confidence and no confidence in the Government (Articles 130 and 131), resignation of the Government (Articles 132 and 133) and dissolution of the National Assembly (Article 109) and similar, while the judicial authority should be independent. However, one of the largest drawbacks of the RS Constitution is contained in the provisions defining the position of the judiciary and the carriers of judicial functions. This primarily refers to the provisions regulating the election of the president of the Supreme Court of Cassation and judges (Articles 144 and 147), then to the insufficiently clearly defined provisions regarding the legal framework that defines the position of courts, legal base of court rulings (Article 142 para. 2, Article 145 para. 2 and Article 149 para. 1), election of public prosecutors and deputies of public prosecutors (Article 153), all of which will be discussed later on.

\section{Article 5. Political parties}

The role of political parties in democratic shaping of the political will of the citizens shall be guaranteed and recognized.

Political parties may be established freely.

Activities of political parties aiming at forced overthrow of constitutional system, violation of guaranteed human or minority rights, inciting racial, national or religious hatred, shall be prohibited.

Political parties may not exercise power directly or submit it to their control.

RS Constitution constitutes a leading role of the political parties in political action and guarantees political pluralism, as is in accordance with the principle of civic democracy proclaimed in Article 1 of the Constitution. Establishing political parties does not require any licensing, therefore, it is sufficient to submit the documents provided by law in order to establish a party and the competent authorities will make entry into the corresponding register. 
Constitution of the Republic of Serbia...

\section{Article 7. Coat of Arms, flag and the national anthem}

The Republic of Serbia shall have coat of arms, flag and national anthem.

The coat of arms of the Republic of Serbia shall be used in the form of the Large Coat of Arms and Small Coat of Arms.

The flag of the Republic of Serbia shall exist and be used as the National Flag and State Flag.

National anthem of the Republic of Serbia shall be official song "Bože pravde".

Appearance and use of the coat of arms, flag and national anthem shall be regulated by law.

\section{Article 9. Capital city}

The capital city of the Republic of Serbia is Belgrade.

In accordance with Article 180 para. 5 of the Constitution, "the status of the City of Belgrade, the capital of the Republic of Serbia, shall be regulated by the Law on the Capital and the Statute of the City of Belgrade. The City of Belgrade shall have competences delegated to the municipality and city by the Constitution and the Law, and other competences may be delegated to it in accordance with the Law on the Capital".

\section{Article 10. Language and script}

Serbian language and Cyrillic script shall be in official use in the Republic of Serbia.

Official use of other languages and scripts shall be regulated by the law based on the Constitution.

Another bad solution that we deem necessary to be altered is contained in this article of the Constitution: "According to this Article the Serbian language and the Cyrillic script are in official use. It is striking that, compared to the 1990 Constitution, there is a decreased protection of linguistic rights of minorities, as Article 8 of that Constitution expressly provided that the Latin alphabet also "shall be officially used in the manner established by law". As it appears from the Articles 14, 18 para. 2 and 75 to 81 of the Constitution, it is clearly the intention of the drafters to have the rights of minorities protected at constitutional level. It is therefore not clear to the Venice Commission for what reasons the legal protection of the use of the Latin alphabet, which is preferred by most of the minorities, is no longer expressly mentioned in the Constitution. This is the more astonishing as, according to Article 20 para. 2 of the Constitution, the attained level of human and minority rights may not be lowered" ${ }^{8}$.

\section{Article 12. Provincial autonomy and local self-government}

State power is restricted by the right of citizens to provincial autonomy and local self-government.

\footnotetext{
${ }^{8}$ Venice Commission, Opinion on the Constitution of Serbia, no. 405/2006, para. 12.
} 


\section{Darian RAKITOVAN}

The right of citizens to provincial autonomy and local self-government shall be subjected only to supervision of constitutionality and legality.

Division of competencies between the central, provincial and local authorities (vertical division of power) is a form of limiting the power that, as an original right of the citizens and a form of limiting the state power, was principally regulated in the basic provisions and regulated in more detail in the part regarding territorial organization (Articles 176-194).

However, we agree with the opinion of the Venice Commission ${ }^{9}$ that it is disappointing that the content of this significant right is not specifically defined in the Constitution, but instead it is almost in its whole left to the legislature to determine the scope of these rights.

\section{Article 14. Protection of national minorities}

The Republic of Serbia shall protect the rights of national minorities.

The State shall guarantee special protection to national minorities for the purpose of exercising full equality and preserving their identity.

\section{Article 15. Gender equality}

The State shall guarantee the equality of women and men and develop equal opportunities policy.

The guarantees of the rights of national minorities are contained within the constitutional guarantees of human and minority rights, in item 3 , of the Second part of the Constitution - Articles 75-82. We believe it to be good that the constitutional guarantees of protection for national minorities and gender equality can be found in the basic provisions of the Constitution.

\section{Article 16. International relations}

The foreign policy of the Republic of Serbia shall be based on generally accepted principles and rules of international law.

Generally accepted rules of international law and ratified international treaties shall be an integral part of the legal system in the Republic of Serbia and applied directly.

Ratified international treaties must be in accordance with the Constitution.

As is the case with some of the previous articles of the Constitution, this article is "off to a good start", however it concludes with a provision that opens the door to various dilemmas and doubts. Namely, what can be deemed as a good solution is that this article predicts that the "foreign policy of the Republic of Serbia shall be based on

${ }^{9}$ Venice Commission, Opinion on the Constitution of Serbia, no. 405/2006, para. 13.

\section{CONSTITUTIONAL LAW REVIEW}


generally accepted principles and rules of international law" and that "the generally accepted rules of international law and ratified international treaties shall be an integral part of the legal system in the Republic of Serbia and applied directly". However, the final sentence of this article according to which the "ratified international treaties must be in accordance with the Constitution" cannot be upheld taking into consideration European integration that Serbia strives for. Namely, according to this provision, it is in fact implied that international treaties, according to their legal power within the internal law, are placed between the Constitution and national laws. In connection with this, the Venice Commission states that Serbian government must uphold the Vienna Convention on the Law of Treaties on an international level, which in Article 27 provides that a member state cannot invoke the provisions of its internal law in order to justify noncompletion of the treaty. The Commission also states if the paragraph 3 of this article with paragraph 2 of Article 167 ("The Constitutional Court shall decide on compliance of ratified international treaties with the Constitution") enables the Constitutional Court to revoke the internal legal power of previously ratified international treaties if they are not in accordance with the Constitution, in order not to violate its international commitment stemming from previously ratified treaties, Serbia would have to either modify the Constitution or cancel the treaty or withdraw from one ${ }^{10}$.

Another issue that must be brought to attention is that constitutional terminology referring to international sources of law is inconsistent, which can lead to various interpretation of constitutional norms in practice. For example, in Article 16 para 1, the term "generally accepted principles of international law" and "rules of international law"; in para. 2 of the same article the legislator uses the phrasing "generally accepted rules of international law"; and "ratified international treaties"; phrasing "international treaties" is used in Article 17 and Article 75 para. 1; "valid international standards of human and minority rights" in Article 18 para. 3; and "the practice of international institutions which supervise their implementation" in Article 18 para. 3 of the Constitution.

\section{Part two - Human and minority rights and freedoms}

The second part of the Constitution relates to human and minority rights and freedoms. It consists of 63 articles (from Article 18 to Article 81), subdivided into three groups: 1. Fundamental principles (Articles 18-22), 2. Human rights and freedoms (Articles 23-74), and 3. Rights of persons belonging to national minorities (Articles 75-81).

In relation to all constitutional matters, one should keep in mind that in the year 2002, in the presence of EU officials, representatives of Serbia and Montenegro and the Federal Republic of Yugoslavia have signed the Treaty of Belgrade creating the State

${ }^{10}$ Venice Commission, Opinion on the Constitution of Serbia, no. 405/2006, para. 14-19. 
Union of Serbia and Montenegro (in continuation, "SCG"). SCG existed from 4 February 2003 until 3 June 2006, when Montenegro, following an independence referendum held on 21 May 2006, declared independence. Existing of SCG was regulated by Constitutional Charter adopted on 4 February 2003.

One of the first legal acts enacted by the State Union of Serbia and Montenegro was the Charter on Human and Minority Rights and Civil Liberties, adopted on the $28^{\text {th }}$ of February, 2003. Considering its announcement in the Constitutional Charter, the Charter on Human and Minority Rights is considered its integral part. This Charter determined that member states govern, ensure and protect human rights in their territory, which de facto enabled the existence of two parallel legal systems regarding the protection of human rights that would have to be mutually coordinated, while on the level of state union these rights were protected in case that they could not be guaranteed in the state communities. Many legal experts were of the opinion that this Charter was very well written and contained numerous good solutions, therefore it was a significant step forward in the field of regulating human rights, as confirmed by the European Commission for Democracy through Law. Considering its high assessment, it was to be expected that these solutions would be included in the text of the new Constitution. However, this did not transgress, so despite it being a visible shift in the right direction compared to the Constitution of 1990, the new RS Constitution still falls behind the aforementioned Charter.

We are of the opinion that Serbia should not have decreased the human rights level guaranteed by the Charter on Human and Minority Rights of the State Union of Serbia and Montenegro, which, unfortunately, has been done several times by the current Constitution.

Related to this, even though the RS Constitution proclaims a relatively large number of protected human rights, there is the issue of the criteria used to select them, considering that it does not, for example, guarantee the right for proper accommodation, food and water, nor does it guarantee a series of rights concerning proper living standard guaranteed by the International Covenant on Economic, Social and Cultural Rights.

Furthermore, it seems that the current Constitution neglects gender equality to a certain degree, and that the Constitution does not adequately deal with discrimination of women. There is no direct prohibition of discrimination based on such notions as sexual orientation and marriage status, while on the other hand, even though the right of mother as a parent to health care is guaranteed, it does not extend to the father. Moreover, the Constitution recognizes marriage as a "community of a man and a woman" (Article 62 para. 2), which in this manner leads to the aforementioned discrimination.

Regarding the right to work, the Constitution failed to guarantee equal pay of men and women for same labor and labor of same value. Furthermore, as another such 
example for a decrease in the protection of human rights compared to the previous level, is that the article guaranteeing partially able-bodied citizens the right to training for a suitable job and providing employment (Article 39) was not copied from the 1990 Constitution, and which proscribes the duty for the country to provide social security to the citizens incapable for work, and who do not have the means of livelihood.

In continuation, unlike the Charter, or even the 1990 Constitution, the 2006 Constitution does not proclaim the right to a private and family life, as guaranteed by Article 8 of the European Convention on Human Rights, but instead it only protects certain aspects of the right to privacy, as are: inviolability of home (Article 40), confidentiality of letters and other means of communication (Article 41) and protection of personal data (Article 42).

We believe that a substantial drawback of the existing Constitution is also the fact that the section regarding human and minority rights often refers to the law, thereby formally degrading human and minority rights protection from the constitutional to the legal level.

Due to limited space, in the continuation we will provide only an itemized list of all articles of this chapter, several articles will be presented whole, while only a certain number of articles, which we believe contain either good or bad solutions deserving of attention, will also be shortly analyzed.

\subsection{Fundamental principles}

\section{Article 18. Direct implementation of guaranteed rights}

Human and minority rights guaranteed by the Constitution shall be implemented directly.

The Constitution shall guarantee, and as such, directly implement human and minority rights guaranteed by the generally accepted rules of international law, ratified international treaties and laws. The law may prescribe manner of exercising these rights only if explicitly stipulated in the Constitution or necessary to exercise a specific right owing to its nature, whereby the law may not under any circumstances influence the substance of the relevant guaranteed right.

Provisions on human and minority rights shall be interpreted to the benefit of promoting values of a democratic society, pursuant to valid international standards in human and minority rights, as well as the practice of international institutions which supervise their implementation.

\section{Article 19. Purpose of constitutional guarantees}

Guarantees for inalienable human and minority rights in the Constitution have the purpose of preserving human dignity and exercising full freedom and equality of each individual in a just, open, and democratic society based on the principle of the rule of law. 


\section{Article 20. Restriction of human and minority rights}

Human and minority rights guaranteed by the Constitution may be restricted by the law if the Constitution permits such restriction and for the purpose allowed by the Constitution, to the extent necessary to meet the constitutional purpose of restriction in a democratic society and without encroaching upon the substance of the relevant guaranteed right.

Attained level of human and minority rights may not be lowered.

When restricting human and minority rights, all state bodies, particularly the courts, shall be obliged to consider the substance of the restricted right, pertinence of restriction, nature and extent of restriction, relation of restriction and its purpose and possibility to achieve the purpose of the restriction with less restrictive means.

The RS Constitution proscribes that guaranteed human and minority rights can be restricted only if the Constitution allows so, and only in the means necessary. Even though it predicts certain principles to be used as guide measures for state authority, unlike the provisions regarding restricting from the European Convention on Human Rights (Article 8 to 11 of the Convention) this provision of the Constitution does not reduce its limitations of rights and liberties for a justified cause, but it proscribes that the restriction is possible by any means "permitted by Constitution" without a specific list of legitimate causes. However, such open phrasing can cause certain problems in interpretation and practical application.

\section{Article 21. Prohibition of discrimination}

All are equal before the Constitution and law.

Everyone shall have the right to equal legal protection, without discrimination.

All direct or indirect discrimination based on any grounds, particularly on race, sex, national origin, social origin, birth, religion, political or other opinion, property status, culture, language, age, mental or physical disability shall be prohibited.

Special measures which the Republic of Serbia may introduce to achieve full equality of individuals or group of individuals in a substantially unequal position compared to other citizens shall not be deemed discrimination.

General provision regarding discrimination is listed amongst the basic constitutional principles and minority rights. The ratio of this constitutional prohibition is to ensure basic presuppositions that all human rights guaranteed by the Constitution are exercised under equal conditions. However, this specific ban is not accompanied by provisions sanctioning its violation, or any that would at least guide the legislator on how to regulate this issue, which we deem to be an omission. 


\section{Constitution of the Republic of Serbia...}

\section{Article 22. Protection of human and minority rights and freedoms}

Everyone shall have the right to judicial protection when any of their human or minority rights guaranteed by the Constitution have been violated or denied, they shall also have the right to elimination of consequences arising from the violation.

The citizens shall have the right to address international institutions in order to protect their freedoms and rights guaranteed by the Constitution.

RS Constitution guarantees two kinds of human rights protection: protection in internal law and international legal protection before international institutions.

As the most important aspect of human rights protection in internal law, the Constitution primarily guarantees protection before court. The right to protection before court has any person whose rights were violated or denied, or freedoms guaranteed by the Constitution (para. 1). All persons have a guaranteed right to independent, impartial and legal tribunal, a right to fair trial (Article 32 para. 1) and the right to equal protection before courts, other state bodies, entities exercising public powers, bodies of the autonomous province and bodies of local self-government (Article 36 para. 1). Protection of human rights before court is completed by legal control of administration (legality control of individual acts of administrative bodies used to decide on a person's right, duty or legally grounded interest - Article 198 para. 2).

Content of the rights regarding the protection of human rights, apart from the right to address the court also includes the right to elimination of all consequences arising from the violation (para. 1).

Apart from the court protection, direct protection of human rights before the Constitutional Court is guaranteed (Article 166 para. 1). Direct constitutional and legal protection of human rights relies on the principle of direct implementation of constitutionally guaranteed rights (Article 18 para. 1) and is realized as a subsidiary form of protection under the conditions determined by the Constitution and by the constitutional appeal procedure (Article 170).

The second form of human rights protection is international-legal protection. The constitution guarantees the right of the individual to address international institutions to protect the freedoms and rights guaranteed by the Constitution (para. 2). However, the Constitution does not specifically proscribe the conditions under which this right can be exercised, so in that aspect, international documents regarding human rights should be relied upon (that are in accordance with provisions of Article 16 para. 1 of the Constitution integral parts of the legal order), which proscribe the conditions and the procedure of exercising the right to the protection of rights before international institutions. We point out that an individual can address international institutions for the protection of human rights only after all legal means in internal law have been exhausted. 


\subsection{Human rights and freedoms}

In the Second part, the Constitution of the Republic of Serbia proscribes a relatively large number of basic human rights and freedoms. As previously stated, the criteria used to select those rights are not clear, considering that certain "common" rights contained in international documents regulating this field are absent, but it can be said that this subgroup covers typical human rights and that they are mostly in accordance with European standards. Basic human rights and liberties regulated in this part of the Constitution of the Republic of Serbia are:

Article 23. Dignity and free development of individuals;

Article 24. Right to life;

Article 25. Inviolability of physical and mental integrity;

Article 26. Prohibition of slavery, servitude and forced labor;

Article 27 Right to freedom and security;

Article 28. Treatment of persons deprived of liberty;

Article 29. Special rights in case of arrest and detention without the decision of the court;

Article 30. Detention;

Article 31. Duration of detention;

Article 32. Right to a fair trial;

Article 33. Special rights of persons charged with a criminal offense;

Article 34. Legal certainty in criminal law;

Article 35. Right to rehabilitation and compensation;

Article 36. Right to equal protection of rights and legal remedy;

Article 37. Rights to legal person;

Article 38. Right to citizenship;

Article 39. Freedom of movement;

Article 40. Inviolability of home;

Article 41. Confidentiality of letters and means of communication;

Article 42. Protection of personal data;

Article 43. Freedom of thought, conscience and religion;

Article 44. Churches and religious communities;

Article 45. Conscientious objection;

Article 46. Freedom of thought and expression;

Article 47. Freedom of expressing national affiliation;

Article 48. Promotion of respect for diversity;

Article 49. Prohibition of inciting racial, ethnic and religious hatred;

Article 50. Freedom of the media;

Article 51. Right to information;

Article 52. Electoral right;

Article 53. Right to participate in management of public affairs; 
Article 54. Freedom of assembly;

Article 55. Freedom of association;

Article 56. Right to petition;

Article 57. Right to asylum;

Article 58. Right to property;

Article 59. Right to inheritance;

Article 60. Right to work;

Article 61. Right to strike;

Article 62. Right to enter into marriage and equality of spouses;

Article 63. Freedom to procreate;

Article 64. Rights of the child;

Article 65. Rights and duties of parents;

Article 66. Special protection of the family, mother, single parent and child;

Article 67. Right to legal assistance;

Article 68. Health care;

Article 69. Social protection;

Article 70. Pension insurance;

Article 71. Right to education;

Article 72. Autonomy of university;

Article 73. Freedom of scientific and artistic creativity;

Article 74. Healthy environment.

We point out that some of the rights in this group have the status of absolutely protected rights and that deviating from this rights is not allowed even in war, or during state of emergency. According to Article 202 para. 4 of the Constitution, such status is guaranteed for the rights in Articles 23, 24, 25, 26, 28, 32, 34, 37, 38, 43, 47, 49, 62, 63, 64 and 78 of the Constitution.

\subsection{Rights of persons belonging to national minorities}

Rights and freedoms of persons belonging to national minorities are systematized in a special - third subgroup, within the part of the Constitution regulating human and minority rights.

Members of national minorities enjoy all human rights and freedoms guaranteed by the Constitution, but also some special, individual and collective rights.

Apart from the rights encompassed in this subgroup discussed later on in the text, within the framework of general provisions about human rights several provisions more closely refer to the rights of national minorities. For example, Article 47 guarantees freedom of expressing national affiliation and explicitly excludes the obligation of declaring national affiliation. The following article, Article 48 , proscribes the possibility of precaution measures in the field of education, culture, information focused on 
promoting and respecting differences, including the differences concerning national or ethnic identity of the citizens. Apart from this general provision, in the group of special rights of persons belonging to national minorities (Article 81) the duty of the Republic of Serbia is confirmed to promote the spirit of tolerance and inter-cultural dialogue in the field of education, culture and information, to take measures for enhancement of mutual respect, understanding and cooperation among all people regardless of their ethnic, cultural, linguistic or religious identity. Provisions of Article 49 prohibit any form of discrimination, as well as provoking or inciting inequality, hatred or intolerance based on nationality, and this prohibition, together with the freedom of expressing national affiliation from Article 47 belong in the group of absolutely protected rights that are not subject to deviation even during the state of emergency or time of war.

\section{Article 75. Basic provision}

Persons belonging to national minorities shall be guaranteed special individual or collective rights in addition to the rights guaranteed to all citizens by the Constitution. Individual rights shall be exercised individually and collective rights in community with others, in accordance with the Constitution, law and international treaties.

Persons belonging to national minorities shall take part in decision-making or decide independently on certain issues related to their culture, education, information and official use of languages and script through their collective rights in accordance with the law.

Persons belonging to national minorities may elect their national councils in order to exercise the right to self-governance in the field of culture, education, information and official use of their language and script, in accordance with the law.

\section{Article 76. Prohibition of discrimination against minorities}

Persons belonging to national minorities shall be guaranteed equality before the law and equal legal protection.

Any discrimination on the grounds of affiliation to a national minority shall be prohibited.

Specific regulations and provisional measures which the Republic of Serbia may introduce in economic, social, cultural and political life for the purpose of achieving full equality among members of a national minority and citizens who belong to the majority, shall not be considered discrimination if they are aimed at eliminating extremely unfavorable living conditions which particularly affect them.

Even though general constitutional provision regarding the prohibition of discrimination from Article 21 includes also the prohibition of discrimination concerning national affiliation, due to its importance for the status of national minorities, the Constitution repeats the prohibition of discrimination even in the framework of special rights of national minorities. 
Furthermore, this article proscribes the possibility of undertaking special measures or passing special regulations in order to remove factual inequality and achieving equality of persons belonging to national minorities in economic, social, cultural and political life, and it explicitly determines nondiscriminatory character of these special regulations and measures.

However, according to para. 3 of this article, the application of these measures is only allowed if they are directed towards eliminating extremely unfavorable living conditions. Therefore, the conditions for passing and the application of these special regulations and measures have been determined more restrictively in the Constitution than in Article 27 para. 4, i.e. in general provisions that prohibit discrimination and that define special measures for the purpose of its removal, considering that according to these provisions the purpose of special measures is achieving full equality of persons or a group of persons who are in essence in unequal position. We are not certain that it is justified that only extremely unfavorable living conditions can justify the application of special measures in favor of national minorities.

In this section, five other, relatively well formulated guarantees are proscribed to the members of national minorities, which are as follows:

\section{Article 77. Equality in administering public affairs}

Members of national minorities shall have the right to participate in administering public affairs and assume public positions, under the same conditions as other citizens.

When taking up employment in state bodies, public services, bodies of autonomous province and local self-government units, the ethnic structure of population and appropriate representation of members of national minorities shall be taken into consideration.

\section{Article 78. Prohibition of forced assimilation}

Forced assimilation of members of national minorities shall be strictly prohibited.

Protection of members of national minorities from all activities directed towards their forced assimilation shall be regulated by the Law.

Undertaking measures, which would cause artificial changes in ethnic structure of population in areas where members of national minorities live traditionally and in large numbers, shall be strictly prohibited.

\section{Article 79. Right to preservation of specificity}

Members of national minorities shall have a right to: expression, preservation, fostering, developing and public expression of national, ethnic, cultural, religious specificity; use of their symbols in public places; use of their language and script; have proceedings also conducted in their languages before state bodies, organisations with delegated public powers, bodies of autonomous provinces and local self-government units, in areas where they make a significant majority of population; education in their 
languages in public institutions and institutions of autonomous provinces; founding private educational institutions; use of their name and family name in their language; traditional local names, names of streets, settlements and topographic names also written in their languages, in areas where they make a significant majority of population; complete, timely and objective information in their language, including the right to expression, receiving, sending and exchange of information and ideas; establishing their own mass media, in accordance with the Law.

Under the Law and in accordance with the Constitution, additional rights of members of national minorities may be determined by provincial regulations.

\section{Article 80. Right to association and cooperation with compatriots}

Members of national minorities may found educational and cultural associations, which are funded voluntarily.

The Republic of Serbia shall acknowledge a specific role of educational and cultural associations of national minorities in their exercise of rights of members of national minorities.

Members of national minorities shall have a right to undisturbed relations and cooperation with their compatriots outside the territory of the Republic of Serbia.

\section{Article 81. Developing the spirit of tolerance}

In the field of education, culture and information, Serbia shall give impetus to the spirit of tolerance and intercultural dialogue and undertake efficient measures for enhancement of mutual respect, understanding and cooperation among all people living on its territory, regardless of their ethnic, cultural, linguistic or religious identity.

\section{Part three - Economic system and public finances}

The third part of the Constitution of the Republic of Serbia titled "Economic system and public finances" consists of 15 special articles divided into two subgroups:

1. Economic system (Articles 82-90);

2. Public finances (Articles 91-96)

The basic principles of the economic system of the country are given in the first subgroup (Article 82 para. 1 - market economy; open and free market; freedom of entrepreneurship; independence of business entities; equality of private and all other types of assets), predict that the Republic of Serbia is a unified economic area with a single commodity, labor, capital and services market (Article 82 para. 2), that freedom of entrepreneurship is guaranteed (Article 83) and can be limited only by law, and only for the purpose of protection people's health, the environment, natural resources and safety of the Republic of Serbia (Article 83 para. 2), that the status on the market is regulated by guaranteeing the equality of all (domestic and foreign persons) on the 


\section{Constitution of the Republic of Serbia...}

market (Article 84 para. 1), and that forbid the acts that, contrary to the law, limit free competition by creating or abusing monopolistic or dominant status (Article 84 para. 2). Furthermore, this subgroup regulates proprietary rights of foreigners (Article 85), guarantees the equality of all types of assets (Article 86), determines what is considered state assets (Article 87), as well as the manner of utilizing and management of land (Article 88). Article 89 contains a constitutional obligation according to which everyone is obliged to protect natural rarities and scientific, cultural and historical heritage, as well as goods of public interest in accordance with the law, and in para. 2 of this article it is specifically proscribed that the Republic of Serbia, autonomous provinces and local self-government are to be held particularly accountable for the protection of heritage. The last article of this subgroup, Article 90 "Protection of consumers" proscribes that it is the duty of the Republic of Serbia to protect consumers, and that it specifically prohibits activities directed against health, security and privacy of the consumers, as well as all dishonest activities on the market.

The second subgroup - public finances consists of: Article 91 - Taxes and other revenues; Article 92 - Budget; Article 93 - Public debt; Article 94 - Balancing development; Article 95 - National Bank of Serbia, and Article 96 - State Audit institution.

\section{Part four - Competences of the Republic of Serbia}

This part of the RS constitution only consists of one article - Article 97. Considering that the constitutional provision defining the areas of competency of the Republic is atypical, maybe even unnecessary for unitary countries, the Venice Commission justifiably states that "in a non-federal state the need for such a Part is not at all obvious" and that this article "be relevant for the distribution of powers between the Republic and the Autonomous provinces, it could have been included in Part VII of the Constitution on Territorial organization"11.

Without further and additional analyses, this article will be presented in its whole:

The Republic of Serbia shall organize and provide for:

1. sovereignty, independence, territorial integrity and security of the Republic of Serbia, its international status and relations with other countries and international organisations;

2. exercise and protection of freedoms and rights of citizens; constitutionality and legality; proceedings before courts and other state bodies; liabilities and sanctions for violation of freedoms and rights of citizens stipulated by the Constitution and for violation of laws, other regulations and general acts; amnesty and pardon for criminal offences;

3. territorial organisation of the Republic of Serbia; system of local self-government;

${ }^{11}$ Venice Commission, Opinion on the Constitution of Serbia, no. 405/2006, para. 47. 
4. defence and security of the Republic of Serbia and its citizens; measures in case of the state of emergency;

5. system of crossing the border and control of the trade in goods, services and passenger traffic over border crossing; status of foreigners and foreign legal entities;

6. single market; legal status of business entities; system of performing particular economic and other activities; commodity reserves; monetary, banking, foreign exchange and customs system; international economic relations; system of foreign credit relations; fiscal system;

7. property and bonded relations and protection of all types of assets;

8. system in the area of labour relations, protection at work, employment, social insurance and other forms of social security; other economic and social relations of public interest;

9. sustainable development; system of protection and improvement of environment; protection and improvement of flora and fauna; production, trade and transport of arms, poisonous, inflammable, explosive, radioactive and other hazardous substances;

10. system in areas of health care, social security, protection of war veterans and the disabled, protection of children, education, culture and protection of cultural goods, sport, public information, system of public services;

11. control of legality of managing resources of legal entities; financial audit of public finances; collection of statistical and other data of public interest;

12. development of the Republic of Serbia, policy and measures for spurring balanced development of particular areas of the Republic of Serbia, including the development of underdeveloped areas; organisation and utilisation of space; scientific and technological development;

13. regime and security in all areas of transport;

14. holidays and symbols of the Republic of Serbia;

15. funding of exercising rights and duties of the Republic of Serbia, stipulated by the Constitution and Law;

16. organisation, competences and work of the bodies of the Republic;

17. other relations of interest to the Republic of Serbia, in accordance with the Constitution.

\section{Part five - Organisation of government}

The constitution makers have decided that Part five of the Constitution titled "Organisation of government" consists of 68 articles, subdivided into 9 groups. Unfortunately, this issue of government organization is also the weakest link of the Constitution of the Republic of Serbia, considering that all these provisions, which, due to their enormous significance for the functioning of a modern democratic state should 


\section{Constitution of the Republic of Serbia...}

be impeccably clear and most importantly should be in accordance with democratic and European standards, contain not a small number of debatable solutions. This primarily refers to the organization of "judicial" authority (judiciary and prosecutor's office).

\subsection{National Assembly}

\section{Article 89. Status of the National Assembly}

The National Assembly shall be the supreme representative body and holder of constitutional and legislative power in the Republic of Serbia.

The Constitution of Serbia proscribes a clear parliamentary system of government considering that National Assembly is the highest representative body. Members of the National Assembly are elected by the citizens in direct elections, by secret ballot (Article 100 para. 1), expressing in this manner sovereignty of the citizens, and that the Assembly has constitutional and legislative power (Article 98 para. 1).

\section{Article 99. Competencies}

The most important group of tasks belonging to the sovereignty of the National Assembly is normative activity. Within this activity, in accordance with the provisions of Article 99, the National Assembly adopts the Constitution and decides on its amendment (Article 99 para. 1, p. 1); it enacts laws and other general acts within the competency of the Republic of Serbia (Article 99 para. 1, p. 7) including the budget and the financial statement (Article 99 para. 1, p. 11); it ratifies international contracts (Article 99 para. 1, p. 4); adopts development plan and spatial plan (Article 99 para. 1, p. 10); adopts defense strategy (Article 99 para. 1, p. 9); partakes in the procedure of adopting the Statute of autonomous province and gives previous approval for the highest legal act of the autonomous province (Article 99 para. 1, p. 8, and Article 185 para. 2); orders measures of departure from human and minority rights in the time of war and emergency (Article 105 para. 1, p. 3, and Article 201 para. 3) within the limitations proscribed by an explicit constitutional provision prohibiting these measures to discriminate on the basis of race, gender, language, national affiliation and social origin (Article 202 para. 2).

Constituent power is shared by the National Assembly and the citizens. Namely, adopting the Constitution is not only the decision of Assembly deputies, but the citizens directly decide on the following constitutional referendum that is mandatory if the subject of the revision are the provisions that the Constitution specifically proscribes a mandatory confirmation in the referendum ${ }^{12}$, or it is optional if the subject of the alterations are other constitutional provisions.

\footnotetext{
12 The National Assembly shall be obliged to put forward the act on amending the Constitution in the republic referendum to have it endorsed, in cases when the amendment of the Constitution pertains to the preamble of
}

CONSTITUTIONAL JURISDICTIONS 


\section{Darian RAKITOVAN}

Legislative power is conducted independently by the National Assembly, and in some cases together with the citizens if, based on the proposal of authorized proponents, it decides that a specific law is called to referendum (Article 108). Certain laws ${ }^{13}$, according to a specific constitutional provision cannot be the subject of decisionmaking in a referendum.

Apart from the normative, the National Assembly also has electoral authority, within the Assembly itself and over other authority bodies in the Republic.

Amongst electoral affairs related to the National Assembly itself, the Constitution proscribes only the election of the president and vice president of the Assembly (Article 104), while the choice to the secretary general of the Assembly, the president and members of working bodies, and other, is regulated by the Rules of Procedure of the National Assembly.

As far as other bodies of power in the Republic are concerned, the Assembly elects and dismisses:

- the Prime Minister and ministers (Article 99 para. 2, p. 1, Article 105 para. 1, p. 9, and Article 127);

- third of the judges of the Constitutional Court (Article 99 para. 2, p. 9, Article 105 para. 1, p. 11, and Article 172 para. 2 and 3);

- President of the Supreme Court of Cassation (Article 99 para. 2, p. 2, Article 105 para. 1, p. 12, and Article 144 para. 1);

- Presidents of courts (Article 99 para. 2, p. 3, and Article 105 para. 1, p. 12);

- Judges (Article 99 para. 2, p. 3, Article 105 para. 1, p. 13, and Article 147 para. 1);

- Republic Public Prosecutor (Article 99 para. 2, p. 3, Article 105 para. 1, p. 12, and Article 158 para. 2);

- Public prosecutors (Article 99 para. 2, p. 3, Article 105 para. 1, p. 12, and Article 159 para. 2);

- Deputy public prosecutors (Article 99 para. 2, p. 3, and Article 159 para. 5);

- the Governor of the National Bank of Serbia (Article 99 para. 2, p. 4, and Article 105 para. 1, p. 14);

- Governor's Council (Article 105 para. 1, p. 14);

- the Civic Defender (Article 99 para. 2, p. 5, Article 105 para. 1, p. 14, and Article 139 para. 3);

- part of the members of the High Judicial Council (Article 153 para. 3);

- part of the members of the State Prosecutor's Council (Article 164 para. 3).

the Constitution, principles of the Constitution, human and minority rights and freedoms, the system of authority, proclamation the state of war and emergency, derogation from human and minority rights in the state of emergency or war or the proceedings of amending the Constitution (Article 203 para. 7).

13 The subject of the referendum may not include duties deriving from international contracts, laws pertaining to human and minority rights and freedoms, fiscal and other financial laws, the budget and financial statement, introduction of the state of emergency and amnesty, as well as issues pertaining to election competences of the National Assembly (Article 108 para. 2). 


\section{Constitution of the Republic of Serbia...}

Apart from these competencies, the provision from Article 99 para. 2, p. 6, determines also the competency of the National Assembly to appoint and dismiss other officials stipulated by the law, for example the Republic Electoral Commission, AntiCorruption Agency etc.

The National Assembly also conducts supervision and control of the Government and other state officials and bodies (Civic Defender, the Governor of the National Bank, security services etc.) that respond to the National Assembly. Accounting for the work of the Government (Article 124, 125) is established by posing parliamentary questions, by proposing interpellation (Article 129) and requesting the vote of confidence in the Government (Article 139).

Apart from the aforementioned competencies, the National Assembly also decides on changes concerning the boarders (Article 99 para. 1, p. 2), amnesty for criminal offences (Article 99 para. 1, p. 12), supervises the work of security services (Article 99 para. 1, p. 6), is competent to decide upon immunity, particularly on the cancelation of immunities of deputies, the President of the Republic, members of the Government and Civic Defender (Article 105 para. 1, p. 7); passes decision upon confirmation of deputies' terms of office (Article 101 para. 3); initiates the procedure for determining responsibility of the President of the Republic and passing the decision regarding their dismissal (Article 118 para. 1 and 2), and performs other functions stipulated by the Constitution and Law (Article 99 para. 3).

\section{Article 100. Constitution of the National Assembly}

The National Assembly shall consist of 250 deputies, who are elected on direct elections by secret ballot, in accordance with the Law.

In the National Assembly, equality and representation of different genders and members of national minorities shall be provided, in accordance with Law.

\section{Article 102. Status of Deputies}

The term of office of the deputy shall begin on the day of confirmation of terms of office in the National Assembly and last four years, that is until the expiry of terms of office of deputies of that session of the National Assembly.

Under the terms stipulated by the Law, a deputy shall be free to irrevocably put his/her term of office at disposal to the political party upon which proposal he or she has been elected a deputy.

Deputy may not be a deputy in the Assembly of the autonomous province, nor an official in bodies of executive government and judiciary, nor may he or she perform other functions, affairs and duties, which represent a conflict of interest, according to the Law.

Election, expiry of the term of office and status of deputies shall be stipulated by the Law. 
One of the most controversial provisions of the current Constitution is provision Article 102 para. 2. We are of the opinion that it limits the freedom of deputies to express their own views and opinions, and it infringes upon the direct relation of the deputies and the electing citizens.

In Article 100, paragraph 1, the Constitution proscribes that the deputies are elected by the citizens through direct elections. The Venice Commission understood such phrasing as a possibility for the electors themselves to determine the composition of the National Assembly, and they deem unacceptable the practice that the political parties may designate after the election the persons to enter the Parliament from their list of persons, thus labeling such practice not in accordance with European standards ${ }^{14}$. Furthermore, this is topped by the unacceptable practice of the so called "blank resignations" of the deputies given to the heads of parties after the elections. Due to the aforementioned, in May of 2011, the Assembly adopted the amendments to the Law on election of the members of Parliament that proscribes that the elected deputy must personally submit a certified resignation letter to the president of the National Assembly, and that after the resignation the deputy mandate is to be assigned to the person next in line according to the order from the electoral list of the party.

\section{Article 104. President and Vice Presidents of the National Assembly Article 105. Method of decision making in the National Assembly Article 106. Sessions}

The National Assembly has a president who represents the National Assembly, convenes its sessions, presides and conducts other functions determined by the Constitution, the Law and the Rules of Procedure of the National Assembly as well as one or more vice presidents of the National Assembly elected by the means of majority of all deputies (Article 104).

The National Assembly is unicameral. It operates on regular and extraordinary sessions. The Constitution predicts that regular sessions take place twice a year: first (spring session) beings on the first work day in March, and the second (autumn) session on the first work day of October. The longest duration of these sessions is 90 days (Article 106 para. 1 and 2). Extraordinary sessions are convoked upon the request of at least one third of deputies or upon the request of the Government, with previously determined agenda (Article 106 para. 3). Based on the Constitution, an exception can be made to convoke the National Assembly without announcement, in the case of declaration of state war or emergency (Article 106 para. 4).

Apart from plenary sessions, part of the function of the National Assembly takes place in working bodies, which can be permanent or temporary, and in caucuses.

${ }^{14}$ Venice Commission, Opinion on the Constitution of Serbia, no. 405/2006, para. 51.

\section{CONSTITUTIONAL LAW REVIEW}




\section{Constitution of the Republic of Serbia...}

The Constitution regulates only the most important issues concerning the activity of the National Assembly, while the Law and the Rules of Procedure more closely regulate the internal organization of the National Assembly, parliamentary procedures and activities of the working bodies and caucuses.

In order to for decision-making to be possible on a plenary session of the National Assembly, two conditions must be met:

1. That a majority of all deputies of the National Assembly is present on the plenary session (quorum) (Article 105 para. 1);

2. That the condition regarding majority vote necessary to decide on laws is met (Article 105 para. 2).

The Constitution proscribes the cases where the absolute, qualified majority is necessary to pass a decision, so the Article 105 para. 2 of the Constitution proscribes that by the majority vote of all deputies the National Assembly can: 1 . Grant amnesty for criminal offenses, 2. Declares and calls off the state of emergency, 3. Orders measures of departure from human and minority rights in the time of war and emergency, 4. Enacts the law by which the Republic of Serbia delegates particular issues falling within its competence to autonomous provinces and local self-government units, 5. Gives previous approval for the Statue of the autonomous province, 6 . Decides on the Rules of Procedure pertaining to its work, 7. Cancels immunities of deputies, the President of the Republic, members of the Government and Civic Defender, 8. Adopts the Budget and financial statement, 9. Elects members of the Government and decides on the end of the term of office of the Government and ministers, 10. Decides on response to interpellation, 11. Elects judges of the Constitutional Court and decides on their dismissal and end of their term of office, 12. Elects the president of the Supreme Court of Cassation, presidents of courts, the Republic Public Prosecutor and public prosecutors and decides on the end of their term in the office, 13. Elects judges and deputy public prosecutors, in accordance with the Constitution, 14. Elects and dismisses the Governor of the National Bank of Serbia, Governors' Council and Civic Defender, 15. Performs other election competencies of the National Assembly. Furthermore, according to para. 3 of this article, the same majority is necessary to pass decisions regarding laws that regulate: 1. Referendum and national initiative, 2. Enjoying of individual and collective rights of members of national minorities, 3. Development and spatial plan, 4. Public debt, 5. Territories of autonomous provinces and local self-government units, 6. Conclusion and ratification of international contracts, 7. Other issues stipulated by the Constitution.

The Constitution also proscribes three cases when the National Assembly decides by a two-third majority of the total number of deputies: adopting a proposal to amend the Constitution (Article 203 para. 3), as well as the acts on amending the Constitution (Article 203 para. 6); and deciding the dismissal of the President of the Republic for the violation of the Constitution (Article 118 para. 1). 


\section{Article 107. Right to propose laws}

A right to propose laws, other regulations and general acts shall belong to every deputy, the Government, assemblies of autonomous provinces or at least 30,000 voters.

The Civic Defender and National Bank of Serbia shall have a right to propose laws falling within their competence.

We point out this article in order to indicate the fact that the conditions for proposing a law have been made more severe compared to the Constitution from the year 1990, according to which the national initiative required 15.000 signatures, while now it requires 30.000 voter signatures.

\section{Article 109. Dissolution of the National Assembly}

The President of the Republic may dissolve the National Assembly, upon the elaborated proposal of the Government.

The Government may not propose dissolution of the National Assembly, if a proposal has been submitted for the vote of no confidence in the Government or if the issue of its confidence has been raised.

The National Assembly shall be dissolved if it fails to elect the Government within 90 days from the day of its constitution.

The National Assembly may not be dissolved during the state of war and emergency.

The President of the Republic shall be obliged to dissolve the National Assembly upon his/her decree, in cases stipulated by the Constitution.

Simultaneously with the dissolution of the National Assembly, the President of the Republic shall schedule elections for deputies, so that elections finish not later than 60 days from the day of their announcement.

The National Assembly, which has been dissolved, shall only perform current or urgent tasks, stipulated by the Law. In case of declaration of the state of war or emergency, its full competence shall be reestablished and last until the end of the state of war, that is, emergency.

\subsection{The President of the Republic}

The President of the Republic is the head of the state. The President's position is regulated by the Constitution, and in according with the specific constitutional provision from Article 121 a special law is passed regulating the President's position in the constitutional system and specifying constitutional provisions related to the President.

While assuming office, the President of the Republic passes an oath before the National Assembly, the content of which is given in para. 4 of Article 114 of the Constitution and is as follows: "I do solemnly swear that I will devote all my efforts to preserve the sovereignty and integrity of the territory of the Republic of Serbia, including 


\section{Constitution of the Republic of Serbia...}

Kosovo and Metohija as its constituent part, as well as to provide exercise of human and minority rights and freedoms, respect and protection of the Constitution and laws, preservation of peace and welfare of all citizens of the Republic of Serbia and perform all my duties conscientiously and responsibly".

Even though the President of the Republic is elected through direct elections, their function in the division of power is not overly substantial. The President could have been given a stronger role especially concerning appointments in independent positions, which is one of the observations of the Venice Commission ${ }^{15}$.

According to the provisions of Article 112 of the RS Constitutions the competencies of the President include two basic groups of tasks.

The first group consists of representative competencies, amongst which are: to represent the Republic of Serbia in the country and abroad (Article 112 para. 1, p. 1); to promulgate laws (Article 112 para. 2, p. 2); to propose a candidate for Prime Minster to the National Assembly (Article 112 para. 1, p. 3); to propose holders of position (Article 112 para. 1, p. 4); to appoint and dismiss ambassadors (Article 112 para. 1, p. 5); to receive letters of credit and revocable letters of credit of foreign diplomatic representatives ratified in Serbia (Article 112 para. 2, p. 6); to grant amnesties (Article 112 para. 1, p. 7); to award honors (Article 112 para. 1, p. 7).

It should be specified that some of these competencies are not exclusively conducted by the President of the Republic and not exclusively on their own initiative, but it is related to the propositions directed by other bodies. Therefore, in accordance with the provisions of Article 112 para. 1, p. 3, and Article 127 para. 1, while proposing a mandatary for the Government, the President is obligated to take into consideration the views of the representatives of elected lists of candidates that have deputies in the National Assembly, while during decision-making about appointing or dismissing ambassadors, the President takes action only if such suggestion is given by the Government.

The second part consists of competencies that, based on content, include part of the functions of executive power. Amongst these functions are: functions related to the area of defense that include: commanding the Army (the President is therefore the supreme commander of the Army) (Article 112 para. 2); appointing, promoting and relieving officers of the Army of Serbia (Article 112 para. 2); the right to reach the decision on the state of emergency together with the President of the National Assembly and the Prime minister, conditioned that the National Assembly is not in the position to convene (Article 200 para. 5); the right to proclaim the state of war together with the President of the National Assembly (Article 201 para. 2); decide upon the measures of derogating from human and minority rights guaranteed by the Constitution (Article 201 para. 4); and co-sign state of emergency (Article 200 para. 5) when the National Assembly is not in the position to convene.

15 Venice Commission, Opinion on the Constitution of Serbia, no. 405/2006, para. 48.

CONSTITUTIONAL JURISDICTIONS 


\section{Darian RAKITOVAN}

The president of the Republic also partially conducts activities in the field of foreign policy. He or she represents the Republic of Serbia in the country and abroad (Article 112 para. 1, p. 1), and conducts protocol activities in the field of foreign policy: receiving letters of credit and revocable letters of credit of foreign diplomatic representatives (Article 112 para. 1, p. 6), and appoints and dismisses ambassadors based on Government proposition (Article 112 para. 1, p. 5).

Furthermore, the President of the Republic partakes in realizing constituent and legislative power, and does so through the right to: submit a proposal to amend the Constitution (Article 203 para. 1); to issue a decree on the promulgation of laws and to request of the National Assembly to reconsider the adoption of a law, with the obligation to list the reasons for doing so (Article 113 para. 1); the right to initiate the proceedings of additional (bot not preceding) assessment of constitutionality and legality of a law or another legal act before the Constitutional Court (Article 168 para. 1). The President of the Republic does not have the right to propose laws, but in accordance with Article 113 of the Constitution: (1) The President of the Republic shall be obliged to issue a decree on promulgation of laws or to return the law for reconsideration with a written explanation to the National Assembly, within maximum 15 days from the day of adoption of the law, that is, not later than within seven days, if the law has been adopted by emergency procedure. (2) If the National Assembly decides to vote again on the law, which has been returned for reconsideration by the President of the Republic, the law shall be adopted by the majority vote from the total number of deputies. (3) The President of the Republic shall be obliged to promulgate the newly adopted Law. (4) If the President of the Republic fails to issue a decree on promulgation of the law within the deadline stipulated by the Constitution, the decree shall be issued by the Chairman of the National Assembly.

The President of the Republic is also competent to make a decision regarding the dissolution of the National Assembly. This can be done on the proposal of the Government (Article 127 para. 1) or directly based on the Constitution (Article 109 para. 5).

And finally, the head of state has the right to also perform tasks related to the election and appointing certain state officials: to appoint at least $1 / 3$ of the judges of choice for the Constitutional court from among at least ten candidates proposed by the National Assembly, meaning 5 out of 15 judges (Article 172 para. 2 and 3) and has the right to propose a list of at least 10 candidates for the judges of the Constitutional Court, 5 of which are to be appointed by the National Assembly (Article 172 para. 2 and 3).

Provisions of Article 116 of the Constitution proscribe that The term of office of the President of the Republic shall last five years and begin from the day of taking of the oath before the National Assembly. If the term of office of the President of the Republic expires during the state of war or emergency, it shall be extended so that it lasts until the expiry of three months from the day of the end of the state of war, that is, of emergency. No one shall be elected to a position of the President of the Republic more 


\section{Constitution of the Republic of Serbia...}

than twice. The term of office of the President of the Republic shall end with expiry of the period of time for which he or she has been elected, by his/her resignation or released of duty. The President of the Republic shall tender his/her resignation to the Chairman of the National Assembly.

\subsection{The Government}

The executive authority in the Republic of Serbia is the Government ${ }^{16}$ (even though a part of the tasks of the government is also conducted by the President of the Republic).

The Government consists of the Prime Minister, one or more Vice Presidents and ministers (Article 125 para. 1).

The ministries formed, the number of the ministers in the Government and the number of the Vice Presidents of the Government is proscribed by the Law on Government.

Article 123 of the Constitution proscribes the competencies of the Government:

1. establish and pursue policy;

2. execute laws and other general acts of the National Assembly;

3. adopt regulations and other general acts for the purpose of law enforcement;

4. propose to the National Assembly laws and other general acts and gives its opinion on those laws and general acts, when another mover proposes them;

5. direct and adjust the work of public administration bodies and perform supervision of their work;

6. administer other affairs stipulated by the Constitution and Law.

The Government is responsible to the National Assembly ${ }^{17}$ for the implementation of the politics of the Republic of Serbia, execution of laws and other general acts, while the ministers are responsible to the Prime Minister, the Government and the National Assembly ${ }^{18}$ for their own work and the condition of the fields related to their ministries.

In accordance with the provisions of Article 127, the candidate for the Prime Minister is proposed by the President, after listening to the opinions of the representatives of electoral lists. The candidate for the Prime Minister is presented to the National Assembly by Government Programme and it proposes its future composition, after which the National Assembly casts a vote on the Government Programme, the Prime Minister and the members of the Government at the same time. In order for the Government to be elected, a majority vote of the total number of state deputies is required. The new Government is elected immediately after constituting the National Assembly, considering that it must be elected within 90 days of constituting the Assembly.

\footnotetext{
${ }^{16}$ Article 122 of the Constitution.

${ }^{17}$ Article 124 of the Constitution.

${ }^{18}$ Article 125 para. 3 of the Constitution.
}

CONSTITUTIONAL JURISDICTIONS 
The mandate of the Government commences with the day of making oath before the National Assembly and it lasts until the expiration of the term of office of the National Assembly that selected it. According to the provisions of Article 128 of the Constitution, the term of office of the Government expires before the period of time which it has been elected by the vote of no confidence, dissolution of the National Assembly, resignation of the President of the Republic and in other cases stipulated by the Constitution, while the term of the office of a member of the Government expires before the period of time for which he or she has been elected by accepting his/her resignation, by the vote of no confidence in the National Assembly and dismissal by the National Assembly, upon the proposal of the Prime Minister.

In the Article 127; Article 128 para. 3, Article 132 and Article 134, the Constitution specifically regulates the status and some of the functions of the Prime Minister, whose position in the legal system of Serbia is rather strong. The Prime Minister: represents the Government (Article 125 para. 2), manages and directs the work of the members of the Government (Article 125 para. 2); takes care of coordinated political activities of the Government (Article 125 para. 2); coordinates the work of members of the Government (Article 125 para. 2); presents the Government's Programme to the National Assembly (Article 127 para. 2); presents the choice of ministers to the National Assembly (Article 127 para. 2); presents the termination of the term of office for a the member of Government to the National Assembly (Article 128 para. 6 and Article 133 para. 2); initiates proceedings for election of a new member of the Government in case that the National Assembly passes a vote of no confidence for a member of the Government Article 130 para. 5); delivers the resignation submitted by a member of the Government to the National Assembly (Article 133 para. 2), has the right to submit resignation to the National Assembly (Article 132).

Together with the president of the National Assembly and the President of the Republic, conditioned that the National Assembly is not in the positon to convene, the Prime Minister: proclaims the state of emergency (Article 200 para. 5); proclaims state of war (Article 200 para. 2), and proscribes the measures for derogating from human and minority rights guaranteed by the Constitution (Article 200 para. 3).

\subsection{Public Administration}

According to the provisions of Article 136, businesses of the public administration in the Republic of Serbia are conducted by the ministries and other public administration bodies. In the same article, the Constitution also proscribes the principles that the position of the public administration is based on, and those are as follows: the principle of independence of public administration; the principle of bounding the public administration by the Constitution and the Law; the principle of responsibility of public administration for its work. 


\section{Constitution of the Republic of Serbia...}

The administrative bodies are formed according to the law: republic administrative bodies are formed on the level of the Republic, provincial bodies are formed in autonomous provinces, and city or municipal administrative bodies are formed in the cities and municipalities. It should be mentioned that administrative bodies include special organizations, such as: secretariats, institutes, directorates.

According to the provisions of Article 137 of the Constitution, titled "Delegation of public powers and public services", in the interest of a more efficient and rational exercise of citizens' rights and duties and satisfying their needs of vital importance for life and work, the Law can stipulate the delegation of performing particular affairs falling within the competence of the Republic of Serbia to the autonomous province and the local self-government unit (para. 1). Furthermore, particular public powers can be delated to enterprises, institutions, organizations and individuals (para. 2), as well as specific bodies through which they perform regulatory function in particular fields or affairs (para. 3). The Republic of Serbia, autonomous provinces and local selfgovernment units can establish public services (para. 4), and their affairs and duties for which they are established, as well as their organization and work are stipulated by the Law (5).

\subsection{Civic Defender}

The Civic Defender shall be independent state body who shall protect citizens' rights and monitor the work of public administration bodies, body in charge of legal protection of proprietary rights and interests of the Republic of Serbia, as well as other bodies and organisations, companies and institutions to which public powers have been delegated.

The Civic Defender shall not be authorised to monitor the work of the National Assembly, President of the Republic, Government, Constitutional Court, courts and Public Prosecutor's Offices.

The Civic Defender shall be elected and dismissed by the National Assembly, in accordance with the Constitution and Law.

The Civic Defender shall account for his/her work to the National Assembly.

The Civic Defender shall enjoy immunity as a deputy. The National Assembly shall decide on the immunity of the Civic Defender.

The Law on the Civic Defender shall be enacted ${ }^{19}$.

In article 138, the Constitution implemented a new institution into the constitutional system of the Republic of Serbia - Civic Defender. The aforementioned provision regulates the status of the Civic Defender in the constitutional system, his/her election and dismissal, granted immunity, the most important competencies and responsibilities. Apart from the aforementioned competencies, in the areas of his/her

${ }^{19}$ Article 58 of the Constitution.

CONSTITUTIONAL JURISDICTIONS 


\section{Darian RAKITOVAN}

competencies, the Civic Defender can propose laws to the National Assembly (Article 107 para. 2) and has the status of official institutor in the procedure of assessing the constitutionality and legality before the Constitutional Court (Article 168 para. 1).

In accordance with the Constitution, election, dismissal and immunity rights of the Civic Defender is decided by the National Assembly (Article 99 para. 1, p. 15, and Article 138 para. 3 and 5), by absolute vote majority of deputies (Article 105 para. 2, p. 14). Even though proscribing a stricter majority for a valid decision on these issues is a kind of protection of the independent position of the Civic Defender, the Venice Commission still stated that "it is regrettable that there is no protection of the Civic Defender against unjustified pre-term dismissal by the National Assembly"20. The Commission justifiably raises the question whether the National Assembly should truly oversee the Civic Defender and whether the Civic Defender should be responsible for his/her work to the National Assembly.

\subsection{The Army of Serbia}

The three articles in the sixth item of Part V, the Constitution only regulates the basic questions that determine the constitutional status of the Army of Serbia: its competencies, deciding upon the use of Army outside the borders, and control over its work. Those articles are:

\section{Article 139. Competencies}

The Army of Serbia shall defend the country from external armed threat and perform other missions and tasks, in accordance with the Constitution, Law and principles of international law, which regulate the use of force.

\section{Article 140. Use of Army outside the borders}

The Army of Serbia may be used outside the borders of the Republic of Serbia only upon the decision of the National Assembly of the Republic of Serbia.

\section{Article 141. Control of the Army of Serbia}

The Army of Serbia shall be subject to democratic and civil control.

The Law on the Army of Serbia shall be enacted.

\section{Courts}

The fifth part of the Constitution that includes provisions regulating government organization, includes also the provisions regarding the legislative system of the Republic of Serbia, in three items: item 7, that refers to the courts, item 8 that refers to

${ }^{20}$ Venice Commission, Opinion on the Constitution of Serbia, no. 405/2006, para. 58.

\section{CONSTITUTIONAL LAW REVIEW}




\section{Constitution of the Republic of Serbia...}

the High Judicial Council, and item 9 that contains systematized provisions regarding public prosecutor's office.

As previously mentioned, the problem of organization of judicial power is in fact a "sore spot" in the Constitution of the Republic of Serbia. If it can be said for the other provisions of the current Constitution that they generally (in most part) correspond with the European standards, some even being above those standards, it is not the case for this chapter of the Constitution. The following text will point out these faults, with particular focus placed on some of the admonitions given in its Opinion on the Constitution of Serbia by the Venice Commission.

\section{Article 142. Judiciary principles}

Judicial power shall be unique on the territory of the Republic of Serbia.

Courts shall be separated and independent in their work and they shall perform their duties in accordance with the Constitution, Law and other general acts, when stipulated by the Law, generally accepted rules of international law and ratified international contracts.

The hearing before the court shall be public and may be restricted only in accordance with the Constitution.

Judges and jurors shall participate in a trial, in the manner stipulated by the Law.

The Law may also regulate that only judges may participate in a trial in particular courts and in particular cases.

The court shall decide on matters within the Council, while the Law may stipulate that a single judge may decide on particular matters.

In the constitutional system of the Republic of Serbia, judicial power is entrusted to the courts (Article 4 para. 2 and Article 143 para. 1). The Constitution proscribes a unity of judicial power on the territory of the entire Republic (Article 142 para. 1), it sets the basic principles of the judicial power and proscribes the types of courts, the organization and the position of the courts, regulates the tenure of judges, as well as the position, election and authority of the High Judicial Council.

Independence and autonomy are the principles that make up the basic framework of the status of courts. Within the rule of law, as one of the guiding constitutional principles that assumes that all authority, including judicial authority is exercised based on and within the limitations of the law, the Constitution links the principles of independence and autonomy of the courts with the principles of limited power and the rule of law (Article 3 and Article 4). Furthermore, the Constitution explicitly proscribes that, in its decision-making, the court is limited only by the Constitution, the law, ratified international treaties, and generally accepted regulations of international law, as well as other general acts, conditioned that such is proscribed by law. 


\section{Article 143. Types of courts}

Judicial power in the Republic of Serbia shall belong to courts of general and special jurisdiction.

Establishing, organisation, jurisdiction, system and structure of courts shall be regulated by the Law.

Provisional courts, courts-martial or special courts may not be established.

The Supreme Court of Cassation shall be the Supreme Court in the Republic of Serbia.

The seat of the Supreme Court of Cassation shall be in Belgrade.

In accordance with the Law on Court Organisation ${ }^{21}$, the courts of general jurisdiction are the basic courts (there are 66 of them in the legal system of the Republic of Serbia), high courts (25), appellate courts (4) and the Supreme Court of Cassation, while courts of special jurisdiction are - commercial courts (16), the Commercial Appellate Court, contravention courts (44), the Contravention Appellate Court, and the Administrative Court.

The Supreme Court of Cassation is the only court that is specifically mentioned in the aforementioned provisions of the highest legal act of Serbia. The Constitution generally proscribes several other issues related to this highest court of the Republic in terms of the manner of election, election period, and ending the term of office of the President of the Supreme Court of Cassation.

\section{Article 144. President of the Supreme Court of Cassation}

President of the Supreme Court of Cassation shall be elected by the National Assembly, upon the proposal of the High Judicial Council and received opinion of the meeting of the Supreme Court of Cassation and competent committee of the National Assembly.

President of the Supreme Court of Cassation shall be elected for the period of five years and may not be reelected.

Term of office of the President of the Supreme Court of Cassation shall terminate before the expiry of the time for which he or she has been elected upon his/her personal request, under the terms stipulated by the Law pertaining to the termination of the term of office of the judge or dismissal for reasons stipulated by the Law pertaining to dismissal of the President of Court.

Decision on the end of term of office of the President of the Supreme Court of Cassation shall be adopted by the National Assembly, in accordance with the Law, while the decision on dismissal shall be adopted upon the proposal of the High Judicial Council.

21 “Official Gazette of RS” no. 116/2008, 104/2009, 101/2010, 31/2011 - st. law, 78/2011 - st. law, 101/2011, $101 / 2013,106 / 2015,40 / 2015$ - st. law and 13/2016. 


\section{Article 145. Court decisions}

The Constitution contains special provisions regarding court decisions and their nature, so it is provided by the Article 145 that the court passes its decisions in the name of the people (para. 1), that they are based on the Constitution and the Law, and the ratified international treaty as well as "regulation passed on the grounds of the Law" (para. 2), that all court decisions are obligatory to all according to an explicit constitutional provision (para. 3), that they cannot be the subject of extrajudicial control (para. 3), but that their decisions can be reconsidered only by an authorized court, in a legal proceedings prescribed by the Law (para. 4). The exception from this basic rule was provided in para. 5 of this article through the institute of pardon and amnesty, as acts of state mercy that allows the punishment sentenced by the court to be partially or fully forgiven even without a court decision.

\section{Article 147. Election of judges}

On proposal of the High Judicial Council, the National Assembly shall elect as a judge the person who is elected to the post of judge for the first time.

Tenure of office of a judge who was elected to the post of judge shall last three years.

In accordance with the Law, the High Judicial Council shall elect judges to the posts of permanent judges, in that or other court.

In addition, the High Judicial Council shall decide on election of judges who hold the post of permanent judges to other or higher court.

The Constitution proscribes the manner of election of judges, in two election procedures, depending on whether the judge is to be elected to the post for the first time, or they are to be elected to permanent post. As far as persons being elected to the post of judge for the first time is concerned, decision regarding the election was given to the National Assembly by the Constitution (para. 1) that decides upon the matter by majority vote of the total number of deputies (Article 105 para. 2, p. 12) based on the proposal of the High Judicial Council. The term of office of the judge elected for the first time is three years, and after that time the judge can be elected for permanent tenure (Article 146). When the judge is elected to the post of permanent judge, the High Judicial Council conducts the election (para. 3) and the National Assembly does not partake in the election procedure.

We support the negative criticism of many, who deem the solution that the National Assembly has a role in the election of judges (and public prosecutors, which will be discussed further on) as bad, which seems to us, has been shown as such many times in practice. We agree with the opinion of the Venice Commission that:

"16. The involvement of parliament in judicial appointments risks leading to a politicisation of the appointments and, especially for judges at the lower level courts, it is difficult to see the added value of a parliamentary procedure. In Serbia, the People's 


\section{Darian RAKITOVAN}

Assembly hitherto has not limited its role to confirming candidates presented by the High Judicial Council but it has rejected a considerable number of such candidates under circumstances where it seemed questionable that the decisions were based on merit. This is not surprising since elections by a parliament are discretionary acts and political considerations will always play a role"22.

Article 149 of the Constitution prescribes that the judge is independent in performing his/her judicial function and is responsible only to the Constitution and the Law, as well as that any influence on a judge in performing his/her function is prohibited. In order to ensure independence and autonomy of the judges, and therefore of judiciary as a whole, which is of crucial importance for the functioning of a legal state and security of its citizens, we must start at the beginning, i.e. from the election to judicial function. In order to remove any possibility of any sort of pressures and (subsequent) "political blackmail" of judges, their election should be solemnly based on objective and essential criteria, and not on political reasons. For this reason, the main, or even exclusive role in appointing in judiciary should be given to one objective body, such as the High Judicial Council (but not in the composition regulated by the current Constitution, which will be discussed later on in the section that deals with the analysis of this body), that would name the best candidates after a lawful and objective procedure of analyzing expertise, qualifications and worthiness of the candidate to hold the position of a judge.

\section{Article 148. Termination of a judge's tenure of office}

A judge's tenure of office shall terminate at his/her own request, upon coming into force of legally prescribed conditions or upon relief of duty for reasons stipulated by the Law, as well as if he/she is not elected to the position of a permanent judge.

The High Judicial Council shall pass a decision on termination of a judge's tenure of office. A judge shall have the right to appeal with the Constitutional Court against this decision. The lodged appeal shall not include the right to lodge a Constitutional appeal.

The proceedings, grounds and reasons for termination of a judge's tenure of office, as well as the reasons for the relief of duty of the President of Court shall be stipulated by the Law.

For judges, the termination of their tenure of office, and particularly their relief of duty, are of vital importance, so it is justified for these issues to be regulated by the Constitution.

However, the manner that the Constitution of the Republic of Serbia has dealt with these extremely important and delicate issues regarding the position of judges, also indirectly for the status of the court and judiciary in general, points to the conclusion that regulation of these issues is primarily left in the hands of the Law.

${ }^{22}$ Venice Commission, Opinion on the Constitution of Serbia, no. 405/2006, para. 65.

\section{CONSTITUTIONAL LAW REVIEW}


Regarding making the decision on the election and the relief of duty of judges, against the decision of the High Judicial Council on termination of tenure of office, the Constitution explicitly proscribes only the right to appeal to the Constitutional Court. Even though the solution that High Judicial Council decides on the termination of judge's tenure is praiseworthy, and that there is the possibility of appealing to the Constitutional Court, we are of the opinion that this matter should be much more precisely and better regulated by the Constitution.

Furthermore, as it was noted by the Venice Commission ${ }^{23}$ a significant drawback is that the Constitution does not contain provisions regarding disciplinary responsibility of the judges, even in the most general form.

Apart from the aforementioned and partially discussed articles regarding the status of judiciary and judges in the constitutional system, the Constitution contains three other articles, which we believe to be fully justified, which contain good solutions and that are well phrased:

\section{Article 150. Non-transferability of judge}

A judge shall have the right to perform his/her judicial function in the court to which he/she was elected, and may be relocated or transferred to another court only on his/her own consent.

In case of revocation of the court or the substantial part of the jurisdiction of the court to which he/she was elected, a judge may exceptionally, without his/her consent, be permanently relocated or transferred to another court, in accordance with the Law.

\section{Article 151. Immunity}

A judge may not be held responsible for his/her expressed opinion or voting in the process of passing a court decision, except in cases when he/she committed a criminal offence by violating the Law.

A judge may not be detained or arrested in the legal proceedings instituted due to a criminal offence committed in performing their judicial function without the approval of the High Judicial Council.

\section{Article 152 Incompatibility of judiciary function}

A judge shall be prohibited to engage in political actions.

Other functions, actions or private interests which are incompatible with the judiciary function shall be stipulated by the Law.

\section{The High Judicial Council}

\section{Article 153. Status, constitution and election}

The High Judicial Council is an independent and autonomous body which shall provide for and guarantee independence and autonomy of courts and judges.

${ }^{23}$ Venice Commission, Opinion on the Constitution of Serbia, no. 405/2006, para. 148. 
The High Judicial Council shall have eleven members.

The High Judicial Council shall be constituted of the President of the Supreme Court of Cassation, the Minister responsible for justice and the President of the authorised committee of the National Assembly as members ex officio and eight electoral members elected by the National Assembly, in accordance with the Law.

Electoral members shall include six judges holding the post of permanent judges, of which one shall be from the territory of autonomous provinces, and two respected and prominent lawyers who have at least 15 years of professional experience, of which one shall be a solicitor, and the other a professor at the law faculty.

Presidents of Court may not be electoral members of the High Judicial Council.

Tenure of office of the High Judicial Council's members shall last five years, except for the members appointed ex officio.

A member of the High Judicial Council shall enjoy immunity as a judge.

\section{Article 154. Jurisdiction of the High Judicial Council}

The High Judicial Council shall appoint and relieve of judges, in accordance with the Constitution and the Law, propose to the National Assembly the election of judges in the first election to the post of judge, propose to the National Assembly the election of the President of the Supreme Court of Cassation as well as presidents of courts, in accordance with the Constitution and the Law, participate in the proceedings of terminating the tenure of office of the President of the Supreme Court of Cassation and presidents of courts, in the manner stipulated by the Constitution and the Law, and perform other duties specified by the Law.

\section{Article 155. Legal remedy}

An appeal may be lodged with the Constitutional Court against a decision of the High Judicial Council, in cases stipulated by the Law.

As far as the status, constitution and election of the High Judicial Council is concerned, in the continuation of the commentary we will cite the admonitions of the Venice Commission stated in the Opinion regarding High Judicial Council in the Republic of Serbia: "69. In all new democracies the Constitutions accord an important role to the High Judicial Council. The Serbian Constitution in Article 153 describes the Council as an independent and autonomous body which guarantees independence and autonomy of courts and judges. One can note a positive change in the wording of this provision in comparison with the 2004 draft Constitution insofar as it is not described any more as a judicial body. Only a court can be a judicial body. The structure of the High Judicial Council is different from the solution chosen in the previous draft Constitution. Serbia has chosen the model with two completely separate bodies, one for judges and one for prosecutors. This is one of the possible solutions existing in European countries. 


\section{Constitution of the Republic of Serbia...}

By contrast, the composition of the High Judicial Council seems flawed. At first sight, the composition seems pluralistic. There are 11 members: the President of the Supreme Court of Cassation, the Minister of Justice, the President of the authorised committee of the National Assembly as members ex officio as well as 6 judges (among them 1 from an Autonomous Province), 1 practising lawyer and 1 professor at a law faculty as elective member. This appearance of pluralism is, however, deceptive. All these members are elected, directly or indirectly, by the National Assembly. The 6 judges are not to be elected by their peers but by the National Assembly, the lawyer not by the Bar Association but by the National Assembly, the professor not by the Law Faculty but by the National Assembly. The judicial appointment process is thus doubly under the control of the National Assembly: the proposals are made by the High Judicial Council elected by the National Assembly and the decisions are then made by the National Assembly itself. This seems a recipe for the politicisation of the judiciary and therefore the provision should be substantially amended"24.

We share the aforementioned opinion to a great extent. Even in the case that the competency to appoint judges is transferred from the National Assembly into the exclusive competency of the High Judicial Council, as suggested before as one of the possible solutions in the new Constitution, we are doubtful that any more significant improvement will be made if the constitution of the High Judicial Council is retained as it was provided in the current Constitution. Therefore, it would be necessary to adopt another, more suitable solution in terms of the number of members and the constitution of the High Judicial Council, that would ensure a more adequate real independence and autonomy of this body in conducting its duty, which would significantly contribute to the overall improvement of the condition of legislature in Serbia. Even though we are slightly skeptical in that sense, we do hope that political will can be mustered to finally, in a suitable manner solve this issue in the new constitution that Serbia should adopt in the near future, and in this way set healthy foundations for efficient, independent and autonomous judiciary for the service of its citizens.

\section{Public Prosecutor's Office}

\section{Article 156. Status and jurisdiction}

Public Prosecutor's Office shall be an independent state body which shall prosecute the perpetrators of criminal offences and other punishable actions, and take measures in order to protect constitutionality and legality.

Public Prosecutor's Office shall perform its function on the grounds of the Constitution, Law, ratified international treaty and regulation passed on the grounds of the Law.

${ }^{24}$ Venice Commission, Opinion on the Constitution of Serbia, no. 405/2006, para. 69 and 70.

CONSTITUTIONAL JURISDICTIONS 


\section{Darian RAKITOVAN}

The Constitution clearly defines Public Prosecutor's Office as independent (but not autonomous) state body, whose basic competencies are: 1 . prosecution of perpetrators of criminal offences, 2. prosecution of perpetrators of other punishable actions, 3. taking measures in order to protect constitutionality and legality.

The Constitution also determines the limits of the independent action of public prosecutor's office that exercises its competencies based on the Constitution, the law, ratified international treaties and regulations made based on the law. As with proscribing the competency framework of judges and the legal basis of court decisions, as well as in the case of determining the basis for the function of public prosecution and determining the borders of its agency, generally accepted regulations of international law have been left out, as well as specifying the nature of "regulations passed on the ground of the Law".

\section{Article 157. Establishment and organization}

Establishment, organisation and jurisdiction of Public Prosecutor's Office shall be specified by the Law.

The Republic Public Prosecutor's Office shall be the supreme Public Prosecutor's Office in the Republic of Serbia.

As far as establishment, organization and competencies of public prosecutor's office is concerned, the Constitution indicates that the law, as the regulation dealing with these issues, and the Constitution itself only regulates the institution of the Republic public prosecutor's office, as a body of state power and the highest public prosecutor's office in the Republic.

\section{Article 158. The Republic Public Prosecutor}

The Republic Public Prosecutor shall perform the function of the Public Prosecutor's Office within the rights and duties of the Republic of Serbia.

The Republic Public Prosecutor shall be elected by the National Assembly, on the Government proposal and upon obtaining the opinion of the authorised committee of the National Assembly.

The Republic Public Prosecutor shall be elected for the period of six years and may be re-elected.

Tenure of office of the Republic Public Prosecutor shall terminate if he/she is not reelected, at his/her own request, upon coming into force of legally prescribed conditions or upon relief of duty for reasons stipulated by the Law.

The decision on termination of tenure of office of the Republic Public Prosecutor shall be adopted by the National Assembly, in accordance with the Law, bearing in mind that it shall pass a decision on relief of duty on the Government proposal. 


\section{Constitution of the Republic of Serbia...}

\section{Article 159. Public Prosecutors and Deputy Public Prosecutors}

A Public Prosecutor shall perform the function of the Public Prosecutor's Office.

A Public Prosecutor shall be elected by the National Assembly, on the Government proposal.

Tenure of office of the Public Prosecutor shall last six years and he/she may be reelected.

A Deputy Public Prosecutor shall stand in for the Public Prosecutor in performing the function of the Public Prosecutor's Office and shall be obliged to act according to his/her instructions.

On proposal of the State Prosecutors Council, the National Assembly shall elect as a Deputy Public Prosecutor the person who is elected to this function for the first time.

Tenure of office of a Deputy Public Prosecutor elected to that function for the first time shall last three years.

In accordance with the Law, the State Prosecutors Council shall elect Deputy Public Prosecutors to permanently perform that function, in that or other Public Prosecutor's Office.

In addition, the State Prosecutors Council shall decide on the election of Deputy Public Prosecutors who permanently perform that function in another or superior Public Prosecutor's Office.

As previously mentioned, the public prosecutor is an independent state body that prosecutes offenders of criminal and other punishable actions, and takes measures in order to protect constitutionality and legality. The head of every public prosecutor's office (basic, higher, appellate, prosecutor's offices with special jurisdiction - Public Prosecutor's Office for Organized Crime, and Public Prosecutor's Office for War Crimes and Republic Public Prosecutor's Office), is the Public Prosecutor, who is entrusted by the Constitution to perform the function of the Public Prosecutor (Article 159 para. 1). Deputies of the Public Prosecutor stand in for the Public Prosecutor (Article 159 para. 4), and are obliged according to such constitutional status to follow the instructions of the Public Prosecutor in performing their tasks.

However, the manner of electing the Republic Public Prosecutor and other heads of Prosecution is not in favor of their independence. Heads of Public Prosecutions, including the highest Republic Public Prosecutor, are elected by the National Assembly, upon the proposal of the Government, and upon previously stated opinion of the authorized National Assembly committee. In that sense, public prosecutors can, without a doubt, be an instrument in the hands of the Government and the parliamentary majority in the National Assembly. The extent to which the election of heads of prosecutor's offices can be abused by the political elite in power is best demonstrated by the example of the election of public prosecutors conducted in the Republic of Serbia, at the end of 2015. Even though this in a way deviates from the concept of this paper, we believe it to be significant to show exactly what imprecise and incomplete 


\section{Darian RAKITOVAN}

provisions in the Constitution can cause (and in other laws as well), as well as the extent of influence of political parties in electing these incumbents of public functions.

What is this really about? Due to expiry of the term of office put into effect at the end of 2015, for 85 basic and higher public prosecutors (including the prosecutor for organized crime and the prosecutor for war crimes), the State Prosecutors Council called for open competition on 09/09/2015. The selection of the public prosecutors terminated on $21 / 12 / 2015$ by voting in the National Assembly created much confusion with the public, doubts into the credibility of the whole process and justifiably raised suspicion that it was all done so due to political, and not public interest, and that the basic criterion for the election was political suitability rather than professional credibility.

According to the Constitution, the laws, and other regulations, the procedure of electing public prosecutors (but not their deputies), should, in short, proceed as follows:

The State Prosecutors Council (in continuation, "SPC") first makes a decision on calling for election for public prosecutors, six months before the expiry of term of office of the Public Prosecutor, at the latest (Article 78 of the Law on Public Prosecutor's Office $^{25}$ (in continuation, "LPPO"); and Article 25 para. 1 of SPC Rules of Procedure) ${ }^{26}$.

The conditions for the election of a Public Prosecutor are expertise, qualifications and worthiness. The general conditions for the election of a Public Prosecutor are citizenship of the Republic of Serbia, meeting the conditions for work in state bodies (determined based on the Law on Employment in Government Agencies ${ }^{27}$ ), law school degree, passed bar exam, and worthiness of being a Public Prosecutor (Article 76 of LPPO). Special conditions, based on the competing location, are concerned with the experience length in positions dealing with law after passing the bar exam (Article 77 of LPPO).

Determining if the candidate meets the conditions of expertise, qualifications and worthiness, the procedure of preparing the nomination of the candidate is done by the State Prosecutors Council (Article 13 of the Law on SPC ${ }^{28}$, in continuation, "LSPC"; Article 80 LPPO and Article 29 of SPC Rules of Procedure).

The conditions referring to actual expertise (not only the expertise assumed based on the degree) and qualifications for the function of public prosecutor are determined in two different ways that depend on previous work experience, i.e. the type of lawrelated jobs, and at what time has the candidate done before competing for the function of public prosecutor. The procedure and the manner of verifying these conditions is determined by the Ordinance on the criteria for the assessment of

\footnotetext{
25 “Official Gazette of RS”, no. 116/2008, 104/2009, 101/2010, 78/2011 - st. law, 101/2011, 38/2012 decision of the C.C., $121 / 2012,101 / 2013,111 / 2014$ - decision of the C.C., $117 / 2014,106 / 2015$ and 63/2016 decision of the C.C.

26 "Official Gazette of RS", no. 55/2009 and 43/2015.

27 “Official Gazette of RS", no. 48/91, 66/91, 44/98 - st. law*, 49/99 - st. law**, 34/2001 - st. law***, 39/2002, 49/2005 - decision of the C.C., 79/2005 - st. law, 81/2005 - corr. of st. law, 83/2005 - corr. of st. law and 23/2013 - decision of the C.C.

28 "Official Gazette of RS", no. 116/2008, 101/2010, 88/2011 and 106/2015.
}

CONSTITUTIONAL LAW REVIEW 
qualification, competence and worthiness of candidates in the procedure of nomination and election of the holders of public prosecution office ${ }^{29}$ (in continuation: Ordinance), passed by the State Prosecutors Council on May 14, 2015. Thus, if the applied candidate occupies the function of public prosecution (the public prosecutor or deputy public prosecutor until the call to open competition) or a judge, determining their expertise and qualifications during the open competition is formed based on the evaluation of their work ${ }^{30}$. The evaluation of their previous work as "extremely successfully completes prosecutorial function" is assigned 50 points, the evaluation of "successfully completes prosecutorial function" is assigned 30 points, and evaluation of "not satisfactory" is not assigned any points. If however, a person that has never held the position of a public prosecutor or a judge applies as the candidate, in that case verifying their knowledge and abilities in a written test ${ }^{31}$ is mandatory, which consists of making prosecutorial decisions and the successfulness of justifying legal stances based on case study. Of course, this test is also awarded points: passed the test with "extremely successful" - 50 points; passed with "successful" - 30 points; and did not pass ${ }^{32}$.

The next part of the procedure is the same for both aforementioned situations, so SPC, based on Article 81 of LPPO, has the obligation to conduct an interview with the candidates. The content of this interview is determined by Article 19 of the Rules of Procedure: "The candidate for the election of public prosecutor presents the program for organization and improvement of the work of public prosecution, which is used to evaluate the candidate's ability to organize work, familiarity with the tasks of the prosecutor's office, commitment to maintaining the reputation of public prosecutor's office in public, and other measures for the work of public prosecutor's office that they are competing for". Evaluations of the aforementioned program of the candidates are expressed by points from 1 to 20 . Therefore, the maximum number of points for a candidate is 70 .

The next step in the procedure of electing public prosecutors is creating a ranking of the candidates, based on their result, i.e. the evaluation of their expertise, qualifications and worthiness (Article 82 para. 1 of LPPO), after which the SPC makes a decision on proposing the candidate to be elected as the public prosecutor and can propose one or more candidates (Article 74 para. 3 of LPPO; Article 35 of SPC The Rules of Procedure), which is delivered to the Government.

The wrong impression should not be made here that the SPC is the authorized proponent of the candidates for the public prosecutor's office. The authorized proponent is in fact the Government of the Republic of Serbia. If the SPC suggests only one candidate, the Government can return such proposition to the State Council, however, on the other hand, the Government cannot propose to the National Assembly

\footnotetext{
29 “Official Gazette of RS", no. 43/2015.

${ }^{30}$ Article 16 and 17 of Rules of Procedure.

${ }^{31}$ Article 17 of Rules of Procedure.

${ }^{32}$ Article 18 para. 1 of Rules of Procedure.
}

CONSTITUTIONAL JURISDICTIONS 
to elect a person that was not on the list of the State Prosecutors Council (Article 74 para. 2-4 of LPPO).

At the end of the electoral procedure, the decision on electing public prosecutors is made by the National Assembly, by means of majority vote of all deputies (Article 105 para. 2, p. 12, of the Constitution).

Let us go back to the aforementioned open competition. Total of 252 candidates applied to this open competition for leadership positions for all higher and basic prosecutor's offices. The SPC conducted the procedure of evaluating the expertise and the qualifications of all candidates, and on November $23^{\text {rd }}$, it finalized the ranking list (with points) of all the applied candidates for all prosecutor's offices, and published such final ranking on its internet page. However, instead of then proposing a list with one or more best placed candidates to the Government of Serbia, the SPC provided a list containing the names of all candidates that applied to the open competition without listing the number points attributed to each candidate. Therefore, this (second) list contained only the name and last name of all the applied candidates and the data regarding the prosecutor's office they competed for, which basically made the whole procedure of evaluating the applied candidates obsolete.

Later on, such action of the SPC caused that in a large number of cases (21 of 51), the Government proposed to elect badly ranked candidates to the National Assembly, which the Assembly had done on December 21, 2015. It was not a rare case that a candidate with a far lower number of points was elected for a position even when there were several candidates with the maximum number of points, or even in some cases the last ranked candidate was elected.

Apart from this, the procedure of electing the prosecutors had another serious fault. Namely, even though the open competition was called for 85 basic and higher public prosecutor's offices, and that there were evaluated candidates for every position, the SPC proposed candidates to the Government for only 53 prosecutor's offices, instead of proposing the candidates for all positions. For the remaining 32 prosecutor's offices, the candidates were not proposed without providing any explanation. What should particularly be pointed out is that, for a significant number of unelected positions, there were candidates evaluated with the maximum number of points in the evaluation procedure. Following this, persons were appointed to the function of state prosecutor on these 32 positions by the Republic Public Prosecutor (without open competition). It is also interesting that in some of the prosecutor's offices, persons that participated in the open competition, some of whom were even the first on the list, have been appointed to executive functions, which is truly inconceivable.

Not even a year after this procedure was completed, the public has still not gotten the answers to numerous questions: the criteria used by the Government and the National Assembly in electing the persons appointed as public prosecutors if those were not the evaluation of expertise and qualifications of the candidates, why were the lower ranked candidates elected on open competition, and why have the candidates for over 
30 public prosecutor's offices been proposed or elected when open competition was called and conducted for them as well, even when in those cases the candidates have also been evaluated by the SPC, some even by the maximum number of points.

However, what is perhaps the most concerning, which is at the same time why so much space was allocated to this issue in our paper, is the fact that in conducting these elections, none of the state bodies have technically broken the Constitution nor the laws from an expert and technical perspective. The regulations have "only" been played by those responsible to enact, implement and protect them.

\section{Article 160. Responsibility}

The Republic Public Prosecutor shall account for the work of the Public Prosecutor's Office and his/her own work to the National Assembly.

Public Prosecutors shall account for the work of the Public Prosecutor's Office and their own work to the Republic Public Prosecutor and the National Assembly, whereas Junior Prosecutors shall account for their work to their immediately superior Public Prosecutor as well.

Deputy Public Prosecutors shall be held responsible for their work to the Public Prosecutor.

\section{Article 161. Termination of Public Prosecutor and Deputy Public Prosecutor's tenure of office}

A Public Prosecutor and Deputy Public Prosecutor may terminate their tenure of office at their own request, upon coming into force of legally prescribed conditions or upon relief of duty for reasons stipulated by the Law. A Public Prosecutor's tenure of office shall terminate even if he/she is not re-elected, and Deputy Public Prosecutor's tenure off office shall terminate if he/she is not permanently elected to that function.

A decision on termination of a Public Prosecutor's tenure of office shall be adopted by the National Assembly, in accordance with the Law, and it shall pass a decision on relief of duty on the Government proposal.

A decision on termination of a Deputy Public Prosecutor's tenure of office shall be passed by the State Prosecutors Council.

A Public Prosecutor and Deputy Public Prosecutor may lodge an appeal with the Constitutional Court against the decision on termination of their tenure of office. The lodged appeal shall not include the right to lodge a Constitutional appeal.

The proceedings, grounds and reasons for termination of a Public Prosecutor and Deputy Public Prosecutor's tenure of office shall be regulated by the Law.

\section{Article 162. Immunity}

A Public Prosecutor and Deputy Public Prosecutor may not be held responsible for the expressed opinion while performing the function of prosecutors, except in cases 


\section{Darian RAKITOVAN}

when a Public Prosecutor or Deputy Public Prosecutor commits a criminal offence by violating the law.

A Public Prosecutor or a Deputy Public Prosecutor may not be detained or arrested in the legal proceedings instituted due to a criminal offence committed in performing the prosecutor's function or service without the approval of the authorised committee of the National Assembly.

\section{Article 163. Incompatibility of prosecutor's function}

Public Prosecutors and Deputy Public Prosecutors shall be prohibited to engage in political actions.

Other functions, activities or private interests which are incompatible with the prosecutor's function shall be stipulated by the Law.

\section{Article 164. Status, constitution and election of the State Prosecutors Council}

The State Prosecutors Council is an autonomous body which shall provide for and guarantee the autonomy of Public Prosecutors and Deputy Public Prosecutors, in accordance with the Law.

The State Prosecutors Council shall have 11 members.

The State Prosecutors Council shall be constituted of the Republic Public Prosecutor, the Minister responsible for justice and the President of the authorised committee of the National Assembly as members ex officio and eight electoral members elected by the National Assembly, in accordance with the Law.

Electoral members shall include six Public Prosecutors or Deputy Public Prosecutors holding permanent posts, of which one shall be from the territory of autonomous provinces, and two respected and prominent lawyers who have at least 15 years of professional experience, of which one shall be a solicitor, and the other a professor at the law faculty.

Tenure of office of the State Prosecutors Council's members shall last five years, except for the members appointed ex officio.

A member of the State Prosecutors Council shall enjoy immunity as a Public Prosecutor.

\section{Article 164. Jurisdiction of the State Prosecutors Council}

The State Prosecutors Council shall propose to the National Assembly the candidates for the first election of a Deputy Public Prosecutor, elect Deputy Public Prosecutors to permanently perform that function, elect Deputy Public Prosecutors holding permanent posts as Deputy Public Prosecutors in other Public Prosecutor's Office, decide in the proceedings of termination of Deputy Public Prosecutors' tenure of office in the manner stipulated by the Constitution and the Law, and perform other duties specified in the Law. 
Constitution of the Republic of Serbia...

More or less generally speaking, all the issues discussed regarding the election of judges can be applied for the election of deputy public prosecutors (Article 159 para. 5-8). The objections we had to the provisions regulating the termination of the term of office for judges and the remark that this issue is not in fact a matter of the Constitution, but the regulation of which is assigned mostly to the law, and also the objections to the composition of the High Judicial Council, can be concurrently be made to the provisions regulating the termination of Public Prosecutor and Deputy Public Prosecutor's tenure of office, or to the composition of the SPC. 